\title{
Does Remote Learning Work? Action Research
}

\author{
Laura Wingler* \\ American College of Education September 2020
}

*Corresponding Author: Laura Wingler, American College of Education September 2020, USA

\begin{abstract}
With the COVID-19 pandemic, all educational institutions across the United States were abruptly pushed into remote learning for the remainder of the 2019-2020 school year and many students continue to participate in some degree of remote learning well into 2020-2021 and possibly will continue to learn remotely or in a hybrid setting well into the foreseeable future. This action research study was conducted to determined whether or not remote instruction works and to identify areas in need of improvement to better prepare both students and educators for the digital future in the post-pandemic world. No one has come out of this year unscathed but regardless, every single person in education, including students, faculty, and administrators have more experience with technology than they did prior to 2020.
\end{abstract}

Keywords: Remote learning, technology, Ed Tech

\section{INTRODUCTION}

Remote learning is viewed as, "something [that] should be able to switch off and on based on need; however, the efficiency of transitioning to remote learning is dependent on preparedness, technology tools, and overall student support infrastructure" (Ray, 2020). With the crisis move to remote learning, many educators were forced into an industry they weren't familiar with - educational technology. While it may be assumed by many that quality learning from a distance requires either a lot tech skills with bells and whistles, or is just a matter of keeping in touch with students while maintaining the traditional methods of face-to-face instruction from a distance, it is no secret that many students, faculty, and administrators are unhappy with the current state of education. However, "Regardless of how and where technology has been used, one may not debate against the comfort and ease that technology has brought to different aspects of everyday life" (Wali, 2020, 237). The use of technology both inside the traditional classrooms and online can serve many purposes. It can be used to help teachers differentiate lessons for students, to engage students, and make education more flexible.

Using action research can help to improve student success, provide guidance to faculty about their remote learning practices, and create a unified approach to education that is beneficial to all. While the goal is this study is not define a problem, it is to evaluate the ways in which other institutions handle an issue so that we can provide solutions and innovation to make things better.

Following is an action plan outlining a current problem at the institution, listing questions for research, reviewing literature, discussing research methodology, creating a data and carrying out a data collection plan, displaying the collected data, analyzing the data, and presenting possible findings and future action. In order to come to a conclusion of better practices, this action research is critical and will focus analytically and systematically on the issue at hand.

\section{PURpose}

Over the last several years, I have developed content for my own courses and designed online courses in addition to being a classroom adjunct professor. One major concern that has been brought up regularly by administration, faculty, and students is whether or not remote learning works and is equal to in-person learning. Currently, instructors have loose guidelines to follow when it comes to using the Learning Management System, In structure by Canvas, in a uniform way, and have little training to do so. Furthermore, without proper training and participation from our faculty, the quality, integrity, and compliance of our courses is compromised. Additionally, faculty are upset when asked to create content and provide visibility in their online classrooms. My institution currently has over 
400sections of remote courses being offered in the fall (due to COVID-19) and over 160distance learning courses running that are developed from master courses implemented by a dedicated elearning, subject-matter-expert, and instructional designer team. Faculty in the same course subject vary greatly in the amount of content they provide to their students as well as assessment type. Students can't seem to understand why the physical appearance of their courses, as well as work expectations are so different based on who their professor is. Additionally, we recently had a team of Instructional Designers state how they think faculty need more training because they do not understand the student's perspective when delivering their courses remotely and how to adjust their delivery methods and content for remote learning situations. They have yet to see any research that proves remote learning is less effective than in-person instruction and the institution does not have distinct guidelines for face to face faculty to follow when running their sections remotely. Not having any policy related to delivering coherent courses remotely, and further investigation on this topic has the support of both administration and the e-Learning department. Conducting action research on this topic could assist in improving our current situation and determine a strategy. The purpose of my research is to determine ways to proactively gain a sense of unity and understanding of the current practices, potential, and needs our faculty have towards remote learning and the impact it may have on student success.

\subsection{Problem Statement}

My research is addressing the following problem: Having loose guidelines for teaching remotely is an ineffective method for supporting students, and faculty, and it is suspected to impact the quality of education and student achievement. The problem is there is no specific expectation for using the Learning Management System (LMS) in a coherent way which results in a lack of consistency between faculty and the rigor of the courses between the face-to-face format and remote. In return, students are confused by the inconsistencies between their faculty and the courses they are enrolled in, are not receiving the high quality education they expected, and become frustrated when their courses are inconsistent and expectations are confusing.

\subsection{Research Questions}

Much like the world of online learning, the internet is flooded with information and data-so much that we need to learn to filter it out before deciding what is useful and what is not. But deciding which data is useful and which is not could potentially cause a gap because, "Data literacy skills can become a powerful tool to inform teacher practice. Teachers need to use data, and they need to do it foremost in a way that is in the interest of their students" (Mandinach, 2015, 28).Through conducting action research on remote learning, I hope to answer the following questions:

1. Why do faculty and students think that remote learning doesn't work?

2. What policies and practices do other schools have for faculty to follow in regards to maintaining high quality in remote learning?

3. How can setting guidelines for remote learning improve student engagement and success, and what should those guidelines be?

\section{Literature REVIEW}

In an effort to gain a better understanding of how remote learning impacts students, faculty, and the overall education of matriculating students, a literature review could prove to be valuable and assist in cultivating the problem. Reading literature and wisdom from peer reviewed research will help me answer my questions and learn more about remote learning in the higher education setting. This research will help in the creation of an action plan that could be shared with administration and faculty for future study, analysis, consideration, and implementation at my institution of higher education.

Wali and Popal, (2020) examined the perceptions of students and the impact and emerging issues of technology on their classroom learning. The study employed a quantitative research design and used a questionnaire as a research method to collect data. The data was collected from a sample of 30 post graduate students. The findings show that social media, gamification, blended learning, E-books, remote learning and self-directed professional development are the technological trends used in their classes. The findings also indicate that technology positively influenced the classroom learning of 
these students. Lastly, the results show that technology is not perceived as an emerging issue that would interfere or hinder the students learning in the classroom.

One of the most interesting parts of the research, in relation to faculty's role in the implementation of educational technology is it was found that, "Instructors should be the center of focus when it comes to introducing a new technology to the class. In fact, when teachers are trained for the certain usage of technology in class, there are more chances that the instructor will improvise new and interesting ways to incorporate more technology in their classes" (Wali, A. Z., \&Popal, A. W., 2020, 244).

The overall findings indicate that most of technological trends are used, on average, once a week and that classroom technology helps students in their classroom learning to a greater extent. While it did not directly study the effects of technology on remote students, it consistently shows how technology in the classroom benefits overall student learning and success. However, taking away technology from classes in which technology is already available will negatively influence on learner's performance. Finally, the findings showed that no significant emerging issues of technology have been identified by the students or are perceived to be a challenge or disturbance to the classroom learning. In fact, the participants of the study found technology to be of great benefit when it comes to aiding their classroom learning. Also, based on the findings of this study, it is suggested that faculty should always be in search to introduce the current technological trends compatible with their classroom environment. This brings me to my next area of research, to study the remote learning environment and factors that influence it.

Dr. Ray's (2020) article on remote learning reported that since it is often enacted during times of heightened stress, it is best not to evoke more stress by increasing the demands of both educators and their students and that providing a structure will nourish instruction. Such structure includes time, communication, technology, and lesson design. Clear definitions and expectations of these elements will help prevent distraction, a common issue found within remote setting. Setting expectations and boundaries for both student and staff in regards to how much time the learning will take offers benefits to managing time in both synchronous and asynchronous experiences; educators need to have set time that they will be available to students. Students will need to be given clear guidelines on how often, which method, and when they should interact with their instructor and with each other (if required).

In addition, faculty need to set clear guidelines on how often they will be available and set the tone for students receiving timely feedback on their assignments. Since technology access varies between students in a remote setting, it is best that students are provided alternative ways to return and receive their assignments and materials. Technological support and issues need to be clearly communicated and addressed to all persons using technology to provide and receive instruction. Lastly, lesson design needs to be appropriate for the remote environment and assessed for the online environment - just because a method works in a face-to-face setting, doesn't mean it translates well into a remote environment.

It was further examined that all educators needs to assume that misunderstanding will occur when delivering instruction remote and to plan for it from the beginning. A list of steps outlined concepts such as, setting the lesson and its context, define the lesson's objectives so that they are clear for students to understand what they will learn, assess learning and comprehension throughout the lesson, introduce content and assess the student's ability to apply it appropriately, and assess the student's mastery of the lesson at the end and suggested a reflective activity. In the end, Dr. Rays suggested to always provide simple and clear instructions, provide grading rubrics, and to consider the role of individual feedback and student responses to continue improving your own teaching methods.

Mannion's (2020) "Education in Transition" article examined the transition of higher education both in-person and online. This article also highlights the changes and strategies across multiple colleges and universities, including Purdue University, Northwest Indiana and Ivy Tech Community College, as a result of the 2020 COVID-19 global pandemic that forced remote learning to take place. As perceived value and enrollment continue to be a major obstacles for nearly all colleges and universities, many are looking to create flexible learning experiences that fit the need of any student wishing to take courses in their preferred format whether that be in-person, remote, hybrid, or fully online. Many of the universities involved are committed to creating more specialized academic degrees and experiences to meet the needs of all students. 
Lederman's (2020) article from Inside Higher Ed on college re-opening plans and remote learning considered 97 Presidents of colleges and universities(including community colleges and four-year colleges and universities) and their comments about their individual institutions. It was found that, Presidents weren't impressed by their colleges' performance in delivering instruction this spring. They also expressed concerns about worries about effective online instruction, student's dissatisfaction with remote learning as a driver to re-open as soon as possible but also admitted that overrating their ability to provide a safe and comfortable physical environment for learning. Overall, a majority of college presidents rated themselves highest in the categories for faculty buy-in and technology support. Maintaining student engagement and ensuring the emotional well-being of students were ranked the lowest within the surveys. Only $34 \%$ said they could ensure that students who wish to remain remote feel sufficiently connected and $57 \%$ felt that they could provide a high-quality, learning experience. Nearly three-quarters (72 percent) say they are very or somewhat concerned about a "perceived decrease in the value of higher education" (Lederman, 2020).

Areas for continued research to address in my data collection include faculty views on their experience with remote learning - the pros and cons and to further define its weaknesses, their perceptions on whether the methods of delivering instruction impact student performance, and if there could be a link between these factors at my institution to better guide faculty and students. I would also like to consider the views of administration and persons working in the field of educational technology. I continue to wonder about how teachers design learning at my institution and the theoretical basis for their approaches. One article reviewed stated that there is evidence that the structure plays a pertinent role in the successful delivery of remote learning and suggests that institutions should follow a systematic approach (Rays, 2020). I would like to know if there are differences in teacher's views of remote learning and the basis for their remote learning pedagogy as well as if and how it can be revised to better serve the students this fall. Lastly, I would like to see if there is any correlating data from my school that could possibly link to any of these findings for future study and analysis of which "online" modalities are best for students and faculty to be successful in.

\section{RESEARCH Methodology/DESIGN}

When it comes to action research, the methodology and design is very important. This research has both descriptive and correlational purposes. Data has been gathered in both qualitative and quantitative measures. In the data collection process, surveys and interviews have conducted and data on community colleges, including enrollment data for Fall 2020 and remote learning guidelines has been reviewed and placed into a table. Two online surveys consisted of questions based on individual teaching approaches, student experiences with technology, pedagogy, educator perceptions of remote learning and past practices from spring 2020. The interviews consisted of open-ended questions expanding on the perceptions of administrators and professionals in the field of educational technology on the practices used during remote learning. Results of the survey, interviews, and public data have been reviewed and analyzed. It was very interesting to see if there was a possible correlation between remote learning guidelines and systematic approaches and performance. While this does not show causality, it could influence future discussion, study, and investigation.

\section{Data Collection}

The three data techniques I believe to be most appropriate for this action research are online teacher surveys, online student (or parent where applicable) surveys, interviews with Administrators and persons working in the field of Educational Technology, and data collected from the public records of educational institutions.

\subsection{Online Teacher Surveys}

Educators across K-12 and Higher Education volunteered to participate in a brief online Google Form survey about their experience; the link was shared on four social media platforms, in groups where both teachers and professors are present. Of the 34educators who participated in the survey, 34 were confirmed to be in active teaching roles in the United States. The survey provides both qualitative and quantitative data. The survey consisted of the following questions:

- Do you teach in NY/NJ/PA/CT? (Yes/No)

○ $100 \%$ responded "Yes" 
- I feel remote learning is... (Successful/Unsuccessful)

○ $\quad 55.9 \%$ Successful; $44.1 \%$ Unsuccessful

- Please select the following grade level that best describes your teaching experience (K-12/2-Year Community College/4-Year College or University/Graduate Level and Up)

- $44 \%$ K-12; 35.3\% 2-Year College; $11.8 \%$ 4-Year College; $8.8 \%$ Graduate Level and up

- My teaching experience is best described as (1-5 years/5-10 years/10-20 years/30 or more years)

○ $14.7 \% 1-5$ years; $38.5 \%$ 5-10 years; $38.2 \% 10-20$ years; $8.8 \% 30+$ years

- My formal education can best be described as (Bachelors/Masters/Terminal Degree such as MFA or MBA/Doctorate Degree in Education/Doctorate Degree in another field/Other)

○ $\quad 20.6 \%$ Bachelors; $64.7 \%$ Master's Degree; $8.8 \%$ Terminal Degree; 5.9\% Doctorate

- Prior to the COVID-19 Pandemic, have you taught in a "remote" or "online" setting before? (Yes to both/No to both/Yes to online only/Yes to remote only)

○ $14.7 \%$ Yes to both; $64.7 \%$ No to both; $20.6 \%$ Yes to online only

- I feel I have received adequate training and/or professional development to teach remotely (Agree/Disagree)

- $\quad 47.1 \%$ Agree; $52.9 \%$ Disagree

- I would rate my comfort in using technology to teach from $1-5$, with 5 being the highest $(1 / 2 / 3 / 4 / 5)$

○ $\quad 0 \%(1) ; 8.8 \%(2) ; 26.5 \%(3) ; 29.4 \%(4) ; 35.3 \%$ (5)

- I received guidelines on how to deliver remote learning from my school or institution...(Yes/No)

○ $26.5 \%$ Yes; $73.5 \%$ No

- Do you agree or disagree with the following statement: "Remote learning doesn't work" (Agree/Strongly Agree/Neutral/Disagree/Strongly Disagree)

○ $23.5 \%$ Agree; $3 \%$ Strongly Agree; 20.6\% Neutral; 35.3\% Disagree; $17.6 \%$ Strongly Disagree

- I felt my students were engaged while receiving remote learning (Agree/Strongly Agree/Neutral/Disagree/Strongly Disagree)

○ $55.9 \%$ Agree; $2.95 \%$ Strongly Agree; $20.6 \%$ Neutral; $17.6 \%$ Disagree; $2.95 \%$ Strongly Disagree

- I enjoy teaching remotely (Agree/Strongly Agree/Neutral/Disagree/Strongly Disagree)

○ $23.5 \%$ Agree; $20.6 \%$ Strongly Agree; $20.6 \%$ Neutral; 23.5\% Disagree; $11.8 \%$ Strongly Disagree

- I felt engaged with my students while teaching remotely (Agree/Strongly Agree/Neutral/Disagree/Strongly Disagree)

○ $61.8 \%$ Agree; $8.8 \%$ Strongly Agree; $8.8 \%$ Neutral; $17.6 \%$ Disagree; 3\% Strongly Disagree

- Which of the following methods did you use while teaching remotely in 2020 ? Check all and any that apply

○ Provided grading rubrics for all assignments (52.9\%)

- Pre-recorded video or screen casting $(67.6 \%)$

○ Live instruction on a tech platform (examples: Zoom, Google Meets, WebEx, Skype, etc) $(64.7 \%)$

- Provided set hours for students to arrange one on one time with me (67.6\%) 
$\circ$ Answered student questions/issues via e-mail (67.6\%)

- Provided students with packets or paper materials (79.4\%)

○ Asked students to turn in all assignments electronically (38.2\%)

○ Asked students to turn in all assignments on paper (64.7\%)

- Asked students for a mix of on-paper and electronic assignments (26.5\%)

- Created opportunities for students to engage with each other (via live sessions or asynchronous tools such as Flipgrid, Voice Thread, discussion boards, etc) (50\%)

- Reviewed and posted expectations for students such as, how long completing a lesson or assignment will take, when assignments are due, and how to submit their work (82.4\%)

- Set clear guidelines that were posted on how and when to contact you (73.5\%)

- Set clear guidelines for receiving extra help with assignments or to ask questions (47.1\%)

- Differentiated content for students (example, provided different ways for them to learn the lesson or complete the assessment) (50\%)

○ Communicated the lesson's learning objective with the students (52.9\%)

- Surveyed student's needs such as technology access, language barriers, 504/IEP accommodations $(72.6 \%)$

○ Used videos from sources like TedEd, YouTube, Khan, etc (72.6\%)

○ Interacted with students regularly/Provided detailed feedback on assignments (67.6\%)

○ Tried to make personal connections with every student on my roster (70.6\%)

○ Asked for student feedback about their learning (52.9\%)

$\circ$ Re-designed my lessons for remote instruction (64.7\%)

- Scanned my paper packets and posted to the LMS (Google Classroom, Blackboard, Canvas, etc) $(38.2 \%)$

- Do you feel that remote learning could be improved by any of the following? Check all that apply

○ Parent involvement (52.9\%)

○ Peer Interaction (55.9\%)

- Small group settings during live instruction (50\%)

- Structured learning schedules (50\%)

○ Additional technology tools (32.4\%)

○ More asynchronous learning (17.6\%)

○ More synchronous learning $(29.4 \%)$

- More one on one opportunities to interact with students (38.2\%)

○ More professional development and/or training for educators (61.8\%)

- More professional development and/or training for administrators or leadership making decisions $(64.7 \%)$

○ More assistance/support for students (and their families where applicable) (47.1\%)

○ More structured communication (38.2\%)

○ More direct instruction (38.2\%)

○ Less direct instruction (2.9\%)

- Flexibility in schedule (50\%) 
○ None listed (2.9\%)

O Other (feedback can be shared at the end) $(0 \%)$

- What, in your opinion, worked and did not work in regards to remote learning? Please share any details you wish from your experience (Short answer). 17 Responded in the following bullets:

- Being in a support role, I didn't see all of my students as they were, often, tired of being on the computer to participate in reading support. There were students that just did not participate at all. During group instruction, it became difficult to manage behaviors when students could "mute" and "unmute" themselves at will. Hopefully with a new platform and additional training things will work more smoothly and effectively. I believe the key is teacher training.

- The hardest students to engage, were the students who did not engage at all. Who felt like they were lost, didn't know where they were supposed to be during the class time, and didn't follow the guides that were in place for them. Students who fell behind, didn't seem to engage enough to catch up. If they did it was merely to just get a passing grade. All students who came into the class and followed the schedule, came to all the classes, and did all the assignments typically did pretty well in classes. Some of that was the quick pivot to online, some of that was students not ready to use all study skills to be successful in remote learning. A few students, who were not doing well in in-person learning, did better at home because of family support and troubleshooting.

- My students are from an inner city and the majority of my students did not have access to any technology and when they did, they refused to/couldn't participate in class due to home environment and lack of structure.

- You will always have those students who push the boundaries and tow the line. It is really important that you set expectations and hold to those. During this unprecedented time, I would also say being somewhat flexible will lead to the success of the individual student.

○ Flexibility

I I had many students who never did any work and parents were difficult to get in touch with.

- Difficulty getting on touch with selected students. Struggled with co-teaching in the Spring.

- I have taught online for the past 8 years with Florida Virtual School. It has been an amazing experience

- The repercussions of work wasn't handed in. Report card did not reflect remote learning

- Many students did not complete assignments even with modification and support from the teacher. Parents did not support their children or help them with the computer or assignments. The kids had a hard time navigating Google classroom. The Wi-Fi was laggy. Some students enjoyed being live with me every day as it created normalcy and consistency. Students had access to the internet to do some independent research. Students learned to use Word and its features which is great!

○ Building community took on a whole new format, but was $100 \%$ worthwhile!

- I teach in a Title 1 special education preschool. The biggest problem I had was parents simply refusing to help their child. I didn't hear from parents for months. However, the parents that did want the support gave very positive feedback. I did lots of online lessons, much like Blues Clues or Dora. The kids and parents liked it

- Teaching the students worked as long as they stayed engaged throughout the lesson just like in class. Keeping them away from distractions. I made sure I had clear expectations what at home learning would look like and it was the same as if we were in the classroom. 
- Having students attend class instead of a preferred activity in the home.

○ 25 percent did not log in and were hard to get in touch with.

- Most of my students did very well with the remote instruction. If a student was not doing well, I immediately reached out and did whatever I could to help them get back on track. Most of them did well with this. If I had to choose, I would much rather be in a classroom to teach; however, if we need to use remote learning for our safety, I believe it can be done. It will not be perfect at first, but neither is everything we do in the classroom. We learn more about the students and adjust as we go, the same should apply here. Our district did not require students to log on for live lessons. That was a mistake in my opinion. If the students are required to $\log$ on, I can teach them. I am nervous about doing this now, because I did not get the chance to do it before, but I am confident that I will figure it out. Our district is not training us on this. Training would be appreciated, but again, I will figure it out. I think we need a combination of video lessons and live lessons because we are teaching to such a variety of learners. This whole process does require the students to be more accountable for their work. Some will have parents who support their education and will keep them on track, some students will not. So we may need to work hard with our guidance counselors and paras to support those students who need it. Our district did not use the paras during the quarantine and I feel that too was a mistake. Those students requiring extra support could have used the help of those paras who were paid and not working. That is unfortunate. Above all, student learning needs to be our main focus. We need to find a way to help ALL of our students be successful during any process of learning. In order to do this we have to work as a team and that team includes: Student, Parent, Teacher, Guidance, Paras, and ALL Administrators. Thank you for asking. I wish you all the best with your research and continued education.

- I'm a special educator. My population was different. I don't believe remote learning works for my population. Maybe some kids it worked but it didn't with mine. My daughter on the other hand is a typical 4th grader and she did it pretty well!

This survey has helped me obtain needed information and results will be analyzed regarding the current practices, skills, beliefs, and attitudes educators have inremote learning. The questions and results of the surveys have been compiled into graphs and a table below.

\subsection{Online Student/Parent Surveys}

Students and parents ranging from K-12 to Higher Education volunteered to participate in a brief online Google Form survey about their experience; the link was shared on three social media platforms, in groups where both students and parents are present. Of the 29 who participated in the survey, 29 were confirmed to be residents of the United States. The survey provides both qualitative and quantitative data. The survey consisted of the following questions:

- Do you attend school in any of the following US States: New York, New Jersey, Pennsylvania, or Connecticut? (Yes/No)

- $100 \%$ Yes

- Which of the following best describes you (Parent/Student)

○ $\quad 62.1 \%$ Parent or Guardian; $37.9 \%$ Student

- My remote experience varied by instructor/teacher (True/False)

○ $82.8 \%$ True; $17.2 \%$ False

- The grade level that best describes my or my child's remote learning experience (K-8/ High School/Community College/4 Year College or University/ Graduate Level/Professional Program or Certificate)

○ K-8 51.7\%; $6.9 \%$ High school; 20.7\% Community College; 13.8\% 4-year college or university; $3.4 \%$ Graduate level; 3.4\% Professional Program

- During remote learning, I or my child had access to 
○ a parent at home to help $(48.3 \%)$

$\circ$ an older sibling at home to help (10.3\%)

$\circ$ tutoring $(17.2 \%)$

- 1:1 help from teachers at my or my child's institution (10.3\%)

$\circ$ none of these $(34.5 \%)$

- I learn better when

$\circ$ The learning experience is synchronous (live, in real time) for a specific time window of hours $(20.7 \%)$

- The learning experience is asynchronous (not live) but needs to occur during a specific time window of days $(13.8 \%)$

○ A mix of both $(65.5 \%)$

- In my experience, I feel that remote learning is... (Successful/Unsuccessful)

○ $55.2 \%$ Successful; $44.8 \%$ Unsuccessful

- Prior to COVID-19, have you (student) enrolled in any type of online educational programming or remote learning situation? (Yes/No)

\section{○ $24.1 \%$ Yes; $75.9 \%$ No}

- Rate the student's comfortability with technology (if parent, rate the child not yourself) 1 being the lowest and 5 being the most comfortable $(1 / 2 / 3 / 4 / 5)$

$$
\text { ○ } 3.4 \% \text { (1); 3.4\% (2); } 17.2 \% \text { (3); } 17.2 \% \text { (4); } 58.6 \% \text { (5) }
$$

- Did your school provide information and guidance on how to access remote learning and what it would entail during? (Yes/No)

○ $\quad 62.1 \%$ Yes; $37 / 9 \%$ No

- Do you agree with the following statement, "Remote learning doesn't work." (Agree/Strongly Agree/Neutral/Disagree/Strongly Disagree)

○ $20.7 \%$ Agree; $20.7 \%$ Strongly Agree; $13.8 \%$ Neutral; 34.5\% Disagree; $10.3 \%$ Strongly Disagree

- I (the student) felt engaged during remote learning, check the following box that closely matches your response (Agree/Strongly Agree/Neutral/Disagree/Strongly Disagree)

○ $37.9 \%$ Agree; $0 \%$ Strongly Agree; $20.7 \%$ Neutral; $17.2 \%$ Disagree; $24.1 \%$ Strongly Disagree

- During your (student's) remote learning experience, please select any of the following that was part of your experience:

- Grading was clearly explained by personalized feedback from my teacher or professor $(20.7 \%)$

- Grading rubrics were provided on assignments and expectations were clear (6.9\%)

- Live instruction was provided via Zoom, Skype, WebEx, Google Meets, or some other program $(24.1 \%)$

- Pre-recorded instruction from my individual teacher was provided as either a video/screen cast $(48.3 \%)$

○ YouTube/TedEd/Khan Academy and other videos were shared (62.1\%)

○ Only work and assignments were posted, no instruction was provided

- My teacher/professor was available to answer my questions and interacted with me $(37.9 \%)$ 
- My teacher/professor was not available to answer my questions and did not interact with me $(27.6 \%)$

- I did not try to contact my teacher at all individually (24.1\%)

- My school sent home paper packets of materials that were needed (13.8\%)

- My assignments were completed entirely online and did not require paper/printer (37.9\%)

- My assignments were completed on paper and needed to be turned in on paper (27.6\%)

$\circ$ My assignments were on paper and needed to be scanned and turned in electronically $(0 \%)$

- I had opportunities to engage with my peers and teacher during remote learning in realtime $(24.1 \%)$

- I had opportunities to engage with my peers and teaching during remote learning asynchronously (via FlipGrid, Pre-recorded media software, VoiceThread, Discussion boards, etc) $(37.9 \%)$

- I understood the expectations for my classes, including what I needed to do, how long it would take, and when it was due $(20.7 \%)$

○ My teacher or professor tried to make personal connections with me (41.4\%)

I I knew where to get help if I had a question (41.4\%)

- I (student) knew how to navigate my online learning system (Google Classroom, Blackboard, Canvas, Moodle, etc) (Yes/No)

○ $86.2 \%$ Yes; $13.8 \%$ No

- Which of the following do you prefer when learning?

○ $\operatorname{Video}(24.1 \%)$

- Audio or Podcast (17.2\%)

○ Reading Text (6.9\%)

$\circ \quad$ Learning from doing something hands-on $(79.3 \%)$

○ Writing or taking notes $(24.1 \%)$

- More of this would help during remote learning...

○ Teacher interaction $(55.2 \%)$

○ Peer Interaction (48.3\%)

○ Working with peers/groups (48.3\%)

○ Structured learning schedules (41.4\%)

○ More technology tools (17.2\%)

○ Less technology tools (6.9\%)

○ More personalized instruction from my teacher/professor (58.6\%)

- More commercial YouTube/Ted/Khan instruction videos (3.4\%)

- More flexibility to work on my own time (20.7\%)

- Clearer guidelines on grading and expectations (44.8\%)

- More engaging lessons/instruction from my teacher/instructor (41.4\%)

- Games to help me learn (17.2\%)

- Individual feedback on my performance (48.3\%)

○ Options for my assignments (27.6\%) 
○ More control to pace my own learning $(24.1 \%)$

- I enjoy learning remotely (Agree/Strongly Agree/Neutral/Disagree/Strongly Disagree) Agree; $10.3 \%$ Strongly Agree; 10.3\% Neutral; 24.1\% Disagree; $17.2 \%$ Strongly Disagree

- What do you feel could have made remote learning a better experience? (Short Answer). 9 Responses pasted below in bullets:

○ More structure and teacher communication/contact. Live instruction

- -More engaging with peers -A daily check in -I like recorded lessons because we can refer back to them. Live instruction is challenging with two working parents.

- Definitely more interaction with teachers and peers. More structured, set schedule to follow. My son does great working independently at his own pace. I need him to learn more on a schedule. Knowing he needs to get something done in a specific amount of time on a scheduled time or day.

- Live lessons with an actual curriculum not just random pages

- ANY teacher interaction. Teachers were not available at all for help. Very delayed responses to requests for help. Had zero live instruction. All lessons were iready or YouTube videos. He was not engaged but rather upset at the lack of teacher interaction. In spite of my attempted contacts, there was still no effort made on the part of educators to interact. The lessons seemed to be busywork.

- As a parent whose child has a learning disability (autism) it is extremely difficult to have them sit and learn via computer when there are other siblings at home that are not in school yet that still need to taken care of. My child needs the hand on learning and in class support and structure that he is not getting at home while learning and the schools are not following the child's IEP when doing virtual learning

- more guidance - but overall I think it's a wonderful thing and the more its used the more its understood

- To give instructions as to how to access assignments. My child struggled navigating through Google classroom and often got confused as to how he can access these assignments. As a result, he missed many assignments and his grades slipped dramatically. I was fortunate though that I had his teacher on speed dial. I'm hoping this time around, teachers will have better knowledge of how to access all assignments.

○ More interaction with teachers. Not just post assignments. Not learning anything new if you have to google answers

This survey has helped me obtain needed information and results will be analyzed regarding the experiences, skills, beliefs, and attitudes students (and parents where applicable) have in remote learning. The questions and results of the surveys have been compiled into graphs and a table below.

\subsection{Interviews With Education Administrators and Technology Professionals}

Leaders and Administrators across K-12 and Higher Education volunteered to interview and answered various questions about remote learning. Various roles from K-12 to Higher Ed were interviewed including Principals, Deans, a VP, and those working in educational technology roles. Of the 9 participants, all were located in the NY/NJ/PA area. The interviews provides qualitative data. The interviews consisted of the following questions:

Question \#1: What do you think is the main difference between remote learning and online learning?

\begin{tabular}{|l|l|}
\hline Interview \#1 & $\begin{array}{l}\text { Remote learning is something that is done out of need and online learning } \\
\text { is more planned and done by choice. }\end{array}$ \\
$\begin{array}{l}\text { Instructional Designer, } \\
\text { Higher Ed }\end{array}$ & \\
\hline $\begin{array}{l}\text { Interview \#2 } \\
\text { Principal, } \text {-12 }\end{array}$ & $\begin{array}{l}\text { I think that online learning is something that families choose to do whereas } \\
\text { remote learning is done in situations like the COVID-19 pandemic. }\end{array}$ \\
\hline $\begin{array}{l}\text { Interview \#3 } \\
\text { Dean, Higher Ed }\end{array}$ & Synchronized teaching \\
\hline
\end{tabular}




\begin{tabular}{|c|c|}
\hline $\begin{array}{l}\text { Interview \#4 } \\
\text { Educational Technology } \\
\text { Facilitator, K-12 }\end{array}$ & $\begin{array}{l}\text { Remote learning should have some more instruction and guidance from } \\
\text { teachers opposed to online learning which can be considered self-paced. }\end{array}$ \\
\hline $\begin{array}{l}\text { Interview \#5 } \\
\text { Dean, Higher Ed }\end{array}$ & Remote Learning is real time instruction at the designated hours of the class \\
\hline $\begin{array}{l}\text { Interview \#6 } \\
\text { Dean, Nursing and Health } \\
\text { Sciences, Higher Ed }\end{array}$ & $\begin{array}{l}\text { Remote offers face to face interaction with students. You can see the } \\
\text { students. }\end{array}$ \\
\hline $\begin{array}{l}\text { Interview \#7 } \\
\text { Principal, } K-12\end{array}$ & $\begin{array}{l}\text { Remote learning requires more accountability on the part of the students } \\
\text { and classes/subjects are scheduled. There is also a feel of more blended } \\
\text { learning with students on the elementary level also using books and other } \\
\text { tasks. Online learning has more flexibility and requires that students be } \\
\text { more self-motivated to complete work. Reliance is on computer apps and } \\
\text { technology. }\end{array}$ \\
\hline $\begin{array}{l}\text { Interview \#8 } \\
\text { Director of Curriculum K- } \\
12\end{array}$ & $\begin{array}{l}\text { Both are dependent upon student motivation but online learning is more } \\
\text { planned whereas remote learning is a mix of teaching styles. }\end{array}$ \\
\hline $\begin{array}{l}\text { Interview \#9 } \\
\text { Associate VP of Academic } \\
\text { Affairs, Higher Ed }\end{array}$ & $\begin{array}{l}\text { Provides more flexibility to the students but requires different approach to } \\
\text { teaching and engaging students. }\end{array}$ \\
\hline $\begin{array}{l}\text { Interview \#10 } \\
\text { Dean, Higher Ed }\end{array}$ & Remote learning has a "live" component that is synchronous. \\
\hline $\begin{array}{l}\text { Interview \#11 } \\
\text { Assistant Dean, Higher Ed }\end{array}$ & $\begin{array}{l}\text { I believe the main difference is that remote classes are synchronous but } \\
\text { online ones are asynchronous }\end{array}$ \\
\hline
\end{tabular}

Question \#2: During the Spring 2020 time when education went remote, what were the biggest obstacles for both your institution and teaching staff?

\begin{tabular}{|c|c|}
\hline $\begin{array}{l}\text { Interview \#1 } \\
\text { Instructional Designer, Higher } \\
\text { Ed }\end{array}$ & $\begin{array}{l}\text { Faculty didn't learn to use the LMS until March } 13 \text { and it became } \\
\text { more about teaching them to communicate with their students as they } \\
\text { learned to navigate their way through. The institution didn't provide } \\
\text { guidelines for instructional-nobody said they would still need to teach } \\
\text { outside of posting work to Blackboard. }\end{array}$ \\
\hline $\begin{array}{l}\text { Interview \#2 } \\
\text { Principal, } K-12\end{array}$ & $\begin{array}{l}\text { About } 8 \% \text { of our families did not have access to the internet to } \\
\text { complete their learning online in our district so our teachers had to } \\
\text { maintain communication via telephone and arrange for printed packet } \\
\text { distribution and returns throughout the second half of the school year. } \\
\text { This required an all hands on deck approach to support our staff and } \\
\text { our students. }\end{array}$ \\
\hline $\begin{array}{l}\text { Interview \#3 } \\
\text { Dean, Higher Ed }\end{array}$ & Technology, enforcing more student empathy \\
\hline $\begin{array}{l}\text { Interview \#4 } \\
\text { Educational } \\
\text { Facilitator, } K-12\end{array}$ & $\begin{array}{l}\text { Discovering ways to keep students engaged through technology and } \\
\text { using effective tools. }\end{array}$ \\
\hline $\begin{array}{l}\text { Interview \#5 } \\
\text { Dean, Higher Ed }\end{array}$ & The faculty were not tech savvy enough to teach live online. \\
\hline $\begin{array}{l}\text { Interview \#6 } \\
\text { Dean, Nursing and Health } \\
\text { Sciences, Higher Ed }\end{array}$ & Providing students with hands on skills. \\
\hline $\begin{array}{l}\text { Interview \#7 } \\
\text { Principal, } K-12 \\
\end{array}$ & Parental support, access to technology \\
\hline $\begin{array}{l}\text { Interview \#8 } \\
\text { Director of Curriculum K-12 }\end{array}$ & $\begin{array}{l}\text { Our teachers weren't trained to teach remotely using the same } \\
\text { techniques they used in person. Remote learning requires a lot of } \\
\text { responsibility on the students and their families to take an active role in } \\
\text { their education and teachers can't always reach a student who isn't } \\
\text { participating or logging in. }\end{array}$ \\
\hline
\end{tabular}




\begin{tabular}{|l|l|}
\hline $\begin{array}{l}\text { Interview \#9 } \begin{array}{l}\text { Associate VP of Academic } \\
\text { Affairs, Higher Ed }\end{array} \\
\text { Interview \#10 }\end{array}$ & $\begin{array}{l}\text { Some F2F faculty were challenged by use of the required technology } \\
\text { to teach remotely. }\end{array}$ \\
Dean, Higher Ed & $\begin{array}{l}\text { Need to train faculty who had limited use of technology; students } \\
\text { without laptops and Wi-Fi access; need for flexibility with students } \\
\text { who were impacted by Covid-19 for health reasons or because they } \\
\text { were essential workers. }\end{array}$ \\
\hline Interview \#11 & $\begin{array}{l}\text { Maintain students' retention, follow up with inactive students and } \\
\text { technological problems }\end{array}$ \\
\hline
\end{tabular}

Question \#3: What Guidelines were in place for remote learning in Spring 2020, and were they enough?

\begin{tabular}{|c|c|}
\hline $\begin{array}{l}\text { Interview \#1 } \\
\text { Instructional Designer, } \\
\text { Higher Ed }\end{array}$ & $\begin{array}{l}\text { Grades had to be posted in Blackboard, weekly attendance for completing the } \\
\text { work, and faculty had to navigate ways to communicate the course } \\
\text { requirements to their students. We gave them tools and training but at the end } \\
\text { of the day, they aren't instructional designers. }\end{array}$ \\
\hline $\begin{array}{l}\text { Interview \#2 } \\
\text { Principal, } K-12\end{array}$ & $\begin{array}{l}\text { Our guidelines were to maintain communications with families and to support } \\
\text { our students the best that they could. For the first two months, from March } \\
\text { until almost May, our teachers did a lot of review and did not introduce any } \\
\text { new materials right away. }\end{array}$ \\
\hline $\begin{array}{l}\text { Interview \#3 } \\
\text { Dean, Higher Ed }\end{array}$ & $\begin{array}{l}\text { Because of the emergency nature of the pandemic, full guidelines were not } \\
\text { created until summer. }\end{array}$ \\
\hline $\begin{array}{l}\text { Interview \#4 } \\
\text { Educational Technology } \\
\text { Facilitator, K-12 }\end{array}$ & Not enough - much more planning was needed. \\
\hline $\begin{array}{l}\text { Interview \#5 } \\
\text { Dean, Higher Ed }\end{array}$ & $\begin{array}{l}\text { The guidelines were the best we could do given the move to remote learning } \\
\text { within a few days. }\end{array}$ \\
\hline $\begin{array}{l}\text { Interview \#6 } \\
\text { Dean, Nursing and } \\
\text { Health Sciences, Higher } \\
\text { Ed }\end{array}$ & $\begin{array}{l}\text { We had been using virtual learning experiences prior to going remote as well } \\
\text { as electronic textbooks. }\end{array}$ \\
\hline $\begin{array}{l}\text { Interview \#7 } \\
\text { Principal, } K-12\end{array}$ & $\begin{array}{l}\text { There were no guidelines in March when we unexpectedly went to remote } \\
\text { learning. Our teachers struggled with getting parents on board with using } \\
\text { technology consistently. As building principal, I required all staff to maintain } \\
\text { a Google Classroom where activities and communication was available to } \\
\text { parents and students. On the district level, much was waived and } \\
\text { accommodated for regarding remote. }\end{array}$ \\
\hline $\begin{array}{l}\text { Interview \#8 } \\
\text { Director of Curriculum } \\
K-12\end{array}$ & $\begin{array}{l}\text { Teachers were mainly reviewing existing concepts and slowly introducing } \\
\text { new levels of the curriculum. We didn't have specific guidelines in place as } \\
\text { far as tech tools or consistency in delivery methods. }\end{array}$ \\
\hline $\begin{array}{l}\text { Interview \#9 } \\
\text { Associate } \quad V P \quad \text { of } \\
\text { Academic } \\
\text { Higher Ed }\end{array}$ & $\begin{array}{l}\text { One can always use more guidelines and training sessions. However, the } \\
\text { challenge is how to get those for whom guidelines are developed learn them } \\
\text { and successfully execute them in such a short time. }\end{array}$ \\
\hline $\begin{array}{l}\text { Interview \#10 } \\
\text { Dean, Higher Ed }\end{array}$ & $\begin{array}{l}\text { Guidelines were reactive, as we addressed problems as they happened. This } \\
\text { was not completely effective. }\end{array}$ \\
\hline $\begin{array}{l}\text { Interview \#11 } \\
\text { Assistant Dean, Higher } \\
\text { Ed }\end{array}$ & $\begin{array}{l}\text { Using WebEx conferencing embedded in Canvas was a of great help. The e- } \\
\text { Learning department efforts were more than enough. }\end{array}$ \\
\hline
\end{tabular}

Question \# 4: During the Spring 2020 time when education went remote, what were the biggest wins or strengths for both your institution and teaching staff and what areas need improvement?

\begin{tabular}{|l|l|}
\hline Interview \#1 & The biggest wins was seeing how eager everyone was to learn and help. Our faculty
\end{tabular} pitched in and we saw a unity among our full-time and adjunct faculty for the first 


\begin{tabular}{|c|c|}
\hline $\begin{array}{l}\text { Instructional } \\
\text { Designer, } \\
\text { Higher Ed }\end{array}$ & $\begin{array}{l}\text { time. But there were majors holes in instruction and meeting the needs of individual } \\
\text { students. }\end{array}$ \\
\hline $\begin{array}{l}\text { Interview \#2 } \\
\text { Principal, } K-12\end{array}$ & $\begin{array}{l}\text { The wins were how our teachers came together to form a learning community and } \\
\text { pushed themselves to learn new skills during unprecedented times. The biggest } \\
\text { struggles were keeping track of the families who weren't engaging online and to find } \\
\text { ways to keep them connected. We sent out videos and segments of our morning } \\
\text { announcements regularly to keep the momentum going and to provide students with } \\
\text { some sense of normalcy. }\end{array}$ \\
\hline Interview \#3 & \\
\hline $\begin{array}{l}\text { Dean, Higher } \\
\text { Ed }\end{array}$ & $\begin{array}{l}\text { Wins: more faculty learned to use technologies that we wanted them to learn for a } \\
\text { long time; Canvas use. Needed improvement: how to use various technologies }\end{array}$ \\
\hline $\begin{array}{l}\text { Interview \#4 } \\
\text { Educational } \\
\text { Technology } \\
\text { Facilitator, } K-12\end{array}$ & $\begin{array}{l}\text { Staff came together to help one another survive the many obstacles thrown our way. } \\
\text { More training on specific tools was definitely needed. }\end{array}$ \\
\hline Interview \#5 & \\
\hline $\begin{array}{l}\text { Dean, Higher } \\
\text { Ed }\end{array}$ & $\begin{array}{l}\text { The faculty were moved to teach and or instruct in a different way. In some instances } \\
\text { they were excited about trying new tools to improve their classes. }\end{array}$ \\
\hline Interview \#6 & \\
\hline $\begin{array}{lr}\text { Dean, } & \text { Nursing } \\
\text { and } & \text { Health } \\
\text { Sciences, } & \text { Higher } \\
\text { Ed }\end{array}$ & $\begin{array}{l}\text { Strengths- Good communication between faculty. Needs Improvement- Proctoring } \\
\text { Services }\end{array}$ \\
\hline $\begin{array}{l}\text { Interview \#7 } \\
\text { Principal, } K-12\end{array}$ & All teachers developed a new sense of the power of technology. \\
\hline $\begin{array}{l}\text { Interview \#8 } \\
\text { Director of } \\
\text { Curriculum } K-12\end{array}$ & $\begin{array}{l}\text { Our teachers were willing to learn new technologies and methods of teaching their } \\
\text { students. Parent involvement is a big factor that needs to be addressed as those } \\
\text { students with active parents do better remotely and those without re struggling. }\end{array}$ \\
\hline $\begin{array}{l}\text { Interview \#9 } \\
\text { Associate VP of } \\
\text { Academic } \\
\text { Affairs, Higher } \\
\text { Ed }\end{array}$ & $\begin{array}{l}\text { The attitude of faculty and staff as well as the approach of leadership team, "we are } \\
\text { all in it together." }\end{array}$ \\
\hline $\begin{array}{l}\text { Interview \#10 } \\
\text { Dean, Higher Ed }\end{array}$ & $\begin{array}{l}\text { The biggest win is that faculty learned new technology and strategies for using } \\
\text { Canvas. Need improvement in mastering use of WebEx. }\end{array}$ \\
\hline $\begin{array}{l}\text { Interview \#11 } \\
\text { Assistant Dean, } \\
\text { Higher Ed }\end{array}$ & $\begin{array}{l}\text { The strength was the experience in online services. As a teacher, I didn't feel any } \\
\text { weakness in transition to remote. My institution already has a strong ground in online } \\
\text { education and online services. Even with professional development trainings, they } \\
\text { were carried out online professionally. What needs to improve, I believe, is a frequent } \\
\text { departmental meetings instead of just team meetings. }\end{array}$ \\
\hline
\end{tabular}

Question\#5: Have you (or your institution) added new or additional guidelines to continue remote learning in the Fall or for the future needs of remote learning at your institution? If so, what?

\begin{tabular}{|l|l|}
\hline $\begin{array}{l}\text { Interview \#1 } \\
\text { Instructional } \\
\text { Designer, Higher } \\
\text { Ed }\end{array}$ & $\begin{array}{l}\text { Yes, we now require faculty to provide synchronized instruction during the } \\
\text { scheduled class times as we remain remote. All videos must be recorded and } \\
\text { accessible to students later. We also brought on additional Instructional Designers to } \\
\text { support our faculty. }\end{array}$ \\
\hline $\begin{array}{l}\text { Interview \#2 Principal, K-12 } \\
\text { For Fall, remote students will be reporting to the Google classroom for the duration } \\
\text { of the shortened school day, about five hours and will experience synchronized } \\
\text { instruction throughout the day from the classrooms where their hybrid peers are in } \\
\text { the classroom. This will ensure that all students have the same learning experience. }\end{array}$ \\
\hline Interview \#3 & \begin{tabular}{l} 
Absolutely. \\
\hline
\end{tabular} \\
\hline
\end{tabular}




\begin{tabular}{|c|c|}
\hline Dean, Higher Ed & \\
\hline $\begin{array}{l}\text { Interview \#4 } \\
\text { Educational } \\
\text { Technology } \\
\text { Facilitator, } K-12\end{array}$ & Yes - set schedules, more trainings \\
\hline $\begin{array}{l}\text { Interview \#5 } \\
\text { Dean, Higher Ed }\end{array}$ & $\begin{array}{l}\text { We require the instructors to have synchronous meetings } 50 \% \text { of theie teaching } \\
\text { time. }\end{array}$ \\
\hline $\begin{array}{lr}\text { Interview } & \# 6 \\
& \\
\text { Dean, } & \text { Nursing } \\
\text { and } & \text { Health } \\
\text { Sciences, } & \text { Higher } \\
\text { Ed } & \\
\end{array}$ & $\begin{array}{l}\text { Yes. Guidelines indicating what remote education is and various educational } \\
\text { offerings. }\end{array}$ \\
\hline $\begin{array}{l}\text { Interview \#7 } \\
\text { Principal, } K-12\end{array}$ & $\begin{array}{l}\text { Yes - more accountability will be required on the part of parents and students. Staff } \\
\text { will be required to use consistent apps, raise the bar, look at assessments to focus in } \\
\text { on important learning. All students received a Chromebook so that in grades } 1 \text { to } 5 \\
\text { we are } 1: 1 \text { in tech. }\end{array}$ \\
\hline $\begin{array}{l}\text { Interview \#8 } \\
\text { Director of } \\
\text { Curriculum } K-12\end{array}$ & $\begin{array}{l}\text { For Fall, all teachers will attend 5-7 full days of training and professional } \\
\text { development to use the same technologies and methods of instruction to maintain a } \\
\text { consistent structure for remote learning in our district. Teachers will be blending } \\
\text { both synchronized and asynchronous instruction and structuring the school day for } \\
\text { both hybrid and remote students to foster more structured and consistent learning. }\end{array}$ \\
\hline $\begin{array}{l}\text { Interview \#9 } \\
\text { Associate VP of } \\
\text { Academic Affairs, } \\
\text { Higher Ed }\end{array}$ & $\begin{array}{l}\text { All F2F courses must have live Internet class, classes are to be recorded, F2F faculty } \\
\text { must be accessible via video chat during their office hours. }\end{array}$ \\
\hline Interview \#10 & $\begin{array}{l}\text { Yes, for fall, we issued clear guidelines and had summer trainings to assist faculty } \\
\text { in learning needed skills, such as designing assignments for remote learning, using } \\
\text { YouTube, peer assessment, wellness... }\end{array}$ \\
\hline $\begin{array}{l}\text { Interview \#11 } \\
\text { Assistant Dean, } \\
\text { Higher Ed }\end{array}$ & $\begin{array}{l}\text { Yes, adapting and purchasing new technological applications to cover the most of } \\
\text { remote educational needs. }\end{array}$ \\
\hline
\end{tabular}

Question \#6: How do you think students view remote learning?

\begin{tabular}{|c|c|}
\hline $\begin{array}{l}\text { Interview \#1 } \\
\text { Instructional } \\
\text { Designer, Higher } \\
\text { Ed }\end{array}$ & I think it makes them nervous and anxious when they don't known what to expect. \\
\hline $\begin{array}{l}\text { Interview \#2 } \\
\text { Principal, } K-12\end{array}$ & $\begin{array}{l}\text { I think that elementary students have really stepped up and embraced it while } \\
\text { missing their regular school routines and events. It just isn't as engaging. }\end{array}$ \\
\hline $\begin{array}{l}\text { Interview \#3 } \\
\text { Dean, Higher Ed }\end{array}$ & Some like it; many would prefer the live classroom \\
\hline $\begin{array}{l}\text { Interview \#4 } \\
\text { Educational } \\
\text { Technology } \\
\text { Facilitator, } K-12\end{array}$ & I feel they find it easy, somewhat boring. \\
\hline $\begin{array}{l}\text { Interview \#5 } \\
\text { Dean, Higher Ed }\end{array}$ & $\begin{array}{l}\text { I'm not sure. Overall, it depends on the experience they had this past spring and } \\
\text { summer. I would say that some may prefer to be in a classroom as they are used to } \\
\text { from high school. }\end{array}$ \\
\hline $\begin{array}{l}\text { Interview \#6 } \\
\text { Dean, Nursing and } \\
\text { Health Sciences, } \\
\text { Higher Ed }\end{array}$ & Not happy with it without some face to face - ability to practice hands-on skills. \\
\hline
\end{tabular}




\begin{tabular}{|l|l|}
\hline Interview \#7 & $\begin{array}{l}\text { It depends on the students. Struggling students have difficulty. Students who are } \\
\text { self motivated and have stronger support enjoyed the experience much more than } \\
\text { those who did not have parental support. }\end{array}$ \\
\hline $\begin{array}{l}\text { Interview \#8 } \\
\text { Curriculum K-12 of }\end{array}$ & $\begin{array}{l}\text { Students don't view remote learning the way they view a typical school day. They } \\
\text { want to do the work and then go and enjoy the rest of their day. }\end{array}$ \\
\hline $\begin{array}{l}\text { Interview \#9 } \\
\text { Associate VP of }\end{array}$ & \\
Higher Ed Affairs, & Those who were online students are fine. Jury is still out for some of F2F students. \\
\hline $\begin{array}{l}\text { Interview \#10 } \\
\text { Dean, Higher Ed }\end{array}$ & $\begin{array}{l}\text { Negatively. I think that they prefer contact with their faculty member, if they } \\
\text { signed up for F2F classes. }\end{array}$ \\
\hline $\begin{array}{l}\text { Interview \#11 } \\
\text { Assistant Dean, } \\
\text { Higher Ed }\end{array}$ & \multicolumn{2}{l}{ Some of them preferred it and some hated it. Hard to tell } \\
\hline
\end{tabular}

Question \#7: How does your faculty/teaching staff view remote learning?

\begin{tabular}{|c|c|}
\hline $\begin{array}{l}\text { Interview \#1 } \\
\text { Instructional } \\
\text { Designer, Higher } \\
\text { Ed }\end{array}$ & $\begin{array}{l}\text { Some faculty love it and found a new passion while others feel more comfortable in } \\
\text { a classroom with tangible materials. }\end{array}$ \\
\hline $\begin{array}{l}\text { Interview \#2 } \\
\text { Principal, } K-12 \\
\end{array}$ & $\begin{array}{l}\text { While my teachers did an incredible job of making videos, reading to their students, } \\
\text { and provided fun games and virtual field trips for their students, I think that their } \\
\text { hearts belong in the brick and mortar classrooms. }\end{array}$ \\
\hline $\begin{array}{l}\text { Interview \#3 } \\
\text { Dean, Higher Ed }\end{array}$ & $\begin{array}{l}50 / 50 \text {. Some want the classroom experience; others are super creative and enjoy } \\
\text { coming up with new ways to reach students. }\end{array}$ \\
\hline $\begin{array}{l}\text { Interview \#4 } \\
\text { Educational } \\
\text { Technology } \\
\text { Facilitator, } K-12\end{array}$ & Challenging \\
\hline $\begin{array}{l}\text { Interview \#5 } \\
\text { Dean, Higher Ed }\end{array}$ & $\begin{array}{l}\text { Again, for some it was quite challenging and they prefer to be in the classroom. For } \\
\text { others, it was an exciting, new experience. }\end{array}$ \\
\hline $\begin{array}{lr}\text { Interview \#6 } \\
\\
\text { Dean, } & \text { Nursing } \\
\text { and } & \text { Health } \\
\text { Sciences, } & \text { Higher } \\
\text { Ed } & \\
\end{array}$ & A challenge. Every day is a new day! \\
\hline $\begin{array}{l}\text { Interview \#7 } \\
\text { Principal, } K-12 \\
\end{array}$ & Nothing replaced in person learning. \\
\hline $\begin{array}{l}\text { Interview \#8 } \\
\text { Director of } \\
\text { Curriculum } K-12\end{array}$ & $\begin{array}{l}\text { Some teachers love it and have blossomed with creativity and innovation whereas } \\
\text { others are unhappy and find themselves struggling to connect with their students. }\end{array}$ \\
\hline $\begin{array}{l}\text { Interview \#9 } \\
\text { Associate VP of } \\
\text { Academic Affairs, } \\
\text { Higher Ed }\end{array}$ & $\begin{array}{l}\text { Varies from faculty to faculty. Majority are exploring the technology and beginning } \\
\text { to like it. }\end{array}$ \\
\hline $\begin{array}{l}\text { Interview \#10 } \\
\text { Dean, Higher Ed }\end{array}$ & With anxiety... \\
\hline Interview \#11 & It depends on the teacher, some teacher does not believe in any kind of delivery but \\
\hline
\end{tabular}


\begin{tabular}{|l|l|} 
Assistant Dean, & face-to-face \\
Higher Ed &
\end{tabular}

Question \#8: What is the most important part of a quality remote learning experience?

\begin{tabular}{|c|c|}
\hline $\begin{array}{l}\text { Interview \#1 } \\
\text { Instructional } \\
\text { Designer, Higher } \\
\text { Ed }\end{array}$ & $\begin{array}{l}\text { Students need to understand what is expected of them and their faculty and how to } \\
\text { succeed in the course. }\end{array}$ \\
\hline $\begin{array}{l}\text { Interview \#2 } \\
\text { Principal, } K-12 \\
\end{array}$ & Consistency, structure and of course, fun! \\
\hline $\begin{array}{l}\text { Interview \#3 } \\
\text { Dean, Higher Ed }\end{array}$ & Forming Connection with the students \\
\hline $\begin{array}{l}\text { Interview \#4 } \\
\text { Educational } \\
\text { Technology } \\
\text { Facilitator, } K-12 \\
\end{array}$ & Engaging students with different lesson techniques \\
\hline $\begin{array}{l}\text { Interview \#5 } \\
\text { Dean, Higher Ed }\end{array}$ & $\begin{array}{l}\text { The learning experience needs to be student centered with active engagement in the } \\
\text { meeting (classroom). }\end{array}$ \\
\hline $\begin{array}{l}\text { Interview \#6 } \\
\text { Dean, Nursing and } \\
\text { Health Sciences, } \\
\text { Higher Ed }\end{array}$ & Students having equipment (computers, internet). \\
\hline $\begin{array}{l}\text { Interview \#7 } \\
\text { Principal, } K-12\end{array}$ & Parental support, curriculum that supports a blended learning model. \\
\hline $\begin{array}{l}\text { Interview \#8 } \\
\text { Director of } \\
\text { Curriculum } K-12\end{array}$ & $\begin{array}{l}\text { Team work-students need a consistent experience with their teachers, their } \\
\text { supports at home, and their access to the materials they need to be successful. This } \\
\text { requires all hands on deck between home and school. }\end{array}$ \\
\hline $\begin{array}{l}\text { Interview \#9 } \\
\text { Associate VP of } \\
\text { Academic Affairs, } \\
\text { HigherEd }\end{array}$ & Faculty accessibility. \\
\hline $\begin{array}{l}\text { Interview \#10 } \\
\text { Dean, Higher Ed }\end{array}$ & Connecting with students through "live" sessions \\
\hline $\begin{array}{l}\text { Interview \#11 } \\
\text { Assistant Dean, } \\
\text { Higher Ed }\end{array}$ & $\begin{array}{l}\text { Instructors' training on using the available technologies and understanding the } \\
\text { students' generation differences }\end{array}$ \\
\hline
\end{tabular}

Question \#9: Was the student experience in remote learning contingent upon their faculty member and is this a positive or negative factor?

\begin{tabular}{|l|l|}
\hline Interview \#1 & \\
$\begin{array}{l}\text { Instructional } \\
\text { Designer, Higher Ed }\end{array}$ & $\begin{array}{l}\text { Yes, but this is always the case. Students get into a course what the faculty put } \\
\text { in and their experience can be influenced by a good or bad faculty member. }\end{array}$ \\
\hline Interview \#2 & $\begin{array}{l}\text { I think every teacher brings a different flavor to their classrooms and that } \\
\text { everyone did their best. }\end{array}$ \\
Principal, K-12 & \begin{tabular}{l} 
Unsure. \\
\hline Interview \#3
\end{tabular} \\
\hline
\end{tabular}




\begin{tabular}{|c|c|}
\hline $\begin{array}{l}\text { Interview \#4 } \\
\text { Educational } \\
\text { Technology } \\
\text { Facilitator, } K-12\end{array}$ & Yes. Some faculty took it as a growth opportunity while others did not. \\
\hline $\begin{array}{l}\text { Interview \#5 } \\
\text { Dean, Higher Ed }\end{array}$ & $\begin{array}{l}\text { The student experience is up to both the student and faculty member regardless } \\
\text { the venue of teaching. It should be a positive factor always. }\end{array}$ \\
\hline $\begin{array}{l}\text { Interview \#6 } \\
\text { Dean, Nursing and } \\
\text { Health } \quad \text { Sciences, } \\
\text { Higher Ed }\end{array}$ & $\begin{array}{l}\text { Yes. The more engaging and supportive faculty were the more successful } \\
\text { student outcomes. }\end{array}$ \\
\hline $\begin{array}{l}\text { Interview \#7 } \\
\text { Principal, } K-12 \\
\end{array}$ & $\begin{array}{l}\text { I feel it was contingent on the parents. I also feel it was contingent upon the } \\
\text { comfort of staff with technology. }\end{array}$ \\
\hline $\begin{array}{l}\text { Interview \#8 } \\
\text { Director } \\
\text { Curriculum } K-12 \quad \text { of } \\
\end{array}$ & $\begin{array}{l}\text { To a point, but it was also contingent upon their home life, family support, and } \\
\text { access to technology as well. }\end{array}$ \\
\hline $\begin{array}{l}\text { Interview \#9 } \\
\text { Associate } \quad V P \quad \text { of } \\
\text { Academic } \\
\text { Higher Ed }\end{array}$ & $\begin{array}{l}\text { Yes, it was. Good faculty who is versatile on use of technology and has } \\
\text { modified his/her teaching to remote modality can create an exceptional } \\
\text { experience for the students. }\end{array}$ \\
\hline $\begin{array}{l}\text { Interview \#10 } \\
\text { Dean, Higher Ed }\end{array}$ & $\begin{array}{l}\text { Yes, to the extent that some faculty were able to pivot and adapt more quickly } \\
\text { than others. Some had higher levels of technological expertise. }\end{array}$ \\
\hline $\begin{array}{l}\text { Interview \#11 } \\
\text { Assistant } \quad \text { Dean, } \\
\text { Higher Ed }\end{array}$ & I do believe that and it should be positive if the teacher is effective. \\
\hline
\end{tabular}

\subsection{Public Data Collected from Educational Institutions in New Jersey}

Public data from K-12 and Higher Education was collected and evaluated to analyze the different ways in which educational institutions are managing their remote learning practices for the fall to determine if they expanded or changed their guidelines and practices from the spring 2020. Three institutions were evaluated within the state of New Jersey including K-12, two-year community colleges, and 4-year public universities. The data collected was based on information gathered and shared from their board members and/or leadership on their publicly accessible pages; all information included is public information.

\section{K-12 School Districts}

\begin{tabular}{|c|c|}
\hline $\begin{array}{l}\text { Name } \\
\text { Institution }\end{array}$ & Data Collected \\
\hline $\begin{array}{l}\text { Hazlet } \\
\text { Township Public } \\
\text { School District, } \\
\text { Hazlet, NJ } \\
\text { (Monmouth } \\
\text { County) }\end{array}$ & $\begin{array}{l}\text { - Superintendent, Scott Ridley, Ed.D, "Our goal is to provide a safe and secure } \\
\text { environment in which our educators, students, and staff can teach and learn." }(9 / 1 / 20 \\
\text { YouTube Channel). This means a strong focus on returning to school. } \\
\text { - } \quad \text { Providing extended professional development opportunities to all teachers, } \\
\text { revised calendar to do so }(8 / 7 / 20 \text { video announcement, YouTube Channel) } \\
\text { - } \quad \text { Posted a professional quality video with closed captioning to the district website } \\
\text { regularly to communicate with the community } \\
\text { - } \quad \text { Prioritized younger students K-4 to receive in-person learning up to } 5 \text { days per } \\
\text { week, Middle/High School students will have } 2 \text { day per week Cohort models with remote } \\
\text { instruction taking place } 1 \text { day per week } \\
\text { - } \quad 3 \text { days of Professional development } 9 / 2,9 / 3 \text { and } 9 / 4 \text { set aside. } \\
\text { - } \quad \text { Remote learning includes daily check in, live or video instruction, small group } \\
\text { collaborations, Synchronous learning with in-person students, Asynchronous activities } \\
\text { such as research, writing, projects and digital tools. } \\
\text { - } \quad \text { Tutoring will be offered for HS students after school in all academic subjects } \\
\text { - } \quad \text { Technology tools: Google Classroom/Google Apps for Education; no other tools }\end{array}$ \\
\hline
\end{tabular}




\begin{tabular}{|c|c|}
\hline & $\begin{array}{l}\text { are listed in public domain but may exist } \\
\text { - } \quad \text { In the spring, learning was delivered through Google classroom }\end{array}$ \\
\hline $\begin{array}{lr}\text { Toms } & \text { River } \\
\text { Public } & \text { School } \\
\text { district, } & \text { Toms } \\
\text { River, NJ (Ocean } \\
\text { County) }\end{array}$ & $\begin{array}{l}\text { - Offering all-remote learning for Fall } 2020 \text { until further notice; special education } \\
\text { students in programs such as autism programming are offered some in-person learning } \\
\text { - } \\
\text { an enhanced virtual learning model of instruction for students." } \\
\text { - } \quad \text { Sessions geared specifically toward special education staff members-- who will } \\
\text { welcome students back for limited in-person instruction-- include executive functioning, } \\
\text { creating behavior plans to assist parents at home, and de-escalation techniques. } \\
\text { - } \quad \text { Remote instruction for fall will include using Google Meets to have some level } \\
\text { of live instruction/interaction daily, self-paced resources for students to revisit/access } \\
\text { materials at their own pace, students will engage in live break-out sessions, Tech tools } \\
\text { such as Jamboard, Pear Deck, Braining Camp, and WhiteboardFi will be used to } \\
\text { engagement, Platforms such as iReady. Study Island, Achieve } 3000 \text {, Exact Path, Reading } \\
\text { Eggs, Mystery Science, BrainPop, and Virtual Science labs will be used to ensure that } \\
\text { digital content is more engaging than a traditional textbook, teachers will bring virtual } \\
\text { learning to a new level } \\
\text { - }\end{array}$ \\
\hline $\begin{array}{l}\text { Pemberton } \\
\text { Township School } \\
\text { District, } \\
\text { Pemberton, NJ } \\
\text { (Burlington } \\
\text { County) }\end{array}$ & $\begin{array}{l}\text { - Starting full-remote, all students provided } 1: 1 \text { technology } \\
\text { - } \\
4 \text { hll students will have live access to their teachers. Elementary will have at least } \\
\text { during their scheduled class time. Grades } 9-12 \text { will have access to teachers every other } \\
\text { day per their schedule and teachers will be available at least } 3 \text { mornings per week for } \\
\text { direct support and one-to-one assistance. State guidelines limit preschoolers to } 1 \text { hour of } \\
\text { screen time daily } \\
\text { - } \quad \text { Remote learning will take place Monday through Friday. Students will be } \\
\text { required to log in for attendance daily. There will be no WIN day or Reinforcement day. } \\
\text { Specials and electives will be provided as scheduled. } \\
\text { - Students in specialized programs will attend school in-person on Mondays and } \\
\text { Wednesdays. } \\
\text { - } \text { In Elementary - Ideally, assignments would be completed right away so that all } \\
\text { students are able to maintain the consistent pace of learning. However, this can be a } \\
\text { significant challenge for young learners who need additional support at home. For those } \\
\text { students, assignments should be submitted by the following Monday morning after } \\
\text { assigned. } \\
\text { - } \\
\text { reinforced and extension of learning is fostered. Students will have } 48 \text { hours to complete } \\
\text { the assignment, unless otherwise assigned by the teacher. } \\
\text { - } \\
\text { Childhood Education requires a } 1 \text { hour time limit on "screen time." Teachers will be } \\
\text { available to support parents. } \\
\text { - } \\
\text { availability each day. } \\
\text { - Secondary- Remote students in grades } 6-8 \text { will have access to their teachers } \\
\text { during the scheduled time of their class. In grades } 9-12 \text {, students will have access to } \\
\text { teachers every other day per their schedule. In addition, teachers in grades } 9 \text { - } 12 \text { will be } \\
\text { available at least } 3 \text { mornings per week from } 8 \text { am - } 9: 20 \text { am for direct support and one- } \\
\text { on-one assistance. }\end{array}$ \\
\hline
\end{tabular}

\section{2-Year Community Colleges}

\begin{tabular}{|c|c|}
\hline $\begin{array}{l}\text { Name of } \\
\text { Institution }\end{array}$ & Data Collected \\
\hline $\begin{array}{l}\text { Bergen } \\
\text { County } \\
\text { Community } \\
\text { College, } \\
\text { Lyndhurst, }\end{array}$ & $\begin{array}{l}\text { Presidents Report to the Board of Trustees Meeting Minutes (July 2020). } \\
\text { Enrollment is down } 16 \% \text { for Fall } 2020 \text { compared to last year } \\
\text { Public Comments: Jen, a student, expressed concerns on structure and guidelines } \\
\text { for professors. Response: Dr. Ross and administration are preparing for the fall semester and } \\
\text { will be implement a program to assist faculty with better instructions and procedures for on- } \\
\text { line teaching. Trustee Ranjan suggested that BCC needs to devote resources, train, support, } \\
\text { and guidelines for the benefit of the faculty and the students. }\end{array}$ \\
\hline
\end{tabular}




\begin{tabular}{|c|c|}
\hline & $\begin{array}{l}\text { Response: Dr. Ross and administration are preparing for the fall semester and will be } \\
\text { implement a program to assist faculty with better instructions and procedures for on-line } \\
\text { teaching. } \\
\text { - } \\
\text { are structured for virtual learning. Response: Dr. Ross and administration are preparing for } \\
\text { the fall semester and will be implement a program to assist faculty with better instructions } \\
\text { and procedures for on-line teaching. Dr. Fisher has instituted a program "Train the Trainer." } \\
\text { This program was instituted with the assistant. }\end{array}$ \\
\hline $\begin{array}{l}\text { Brookdale } \\
\text { Community } \\
\text { College, } \\
\text { Lincroft, NJ. }\end{array}$ & $\begin{array}{l}\text { Board of Trustees Meeting (July 2020), Total degree seeking student enrollment is } \\
\text { down - } 19.2 \% \text { for Fall } 2020 \text {. } \\
\text { Public Comments: Jack Ryan, Assistant Professor, English, - expressed concerns } \\
\text { for the College's plans for the fall semester. He suggested that we need to focus on making } \\
\text { the student experience the best possible if we are offering courses via an online experience. } \\
\text { He suggested that we run mock Zoom classes prior to the first day of class to ensure } \\
\text { students are comfortable with the technology. In addition, he suggested to change the past } \\
\text { protocol of changing the Brookdale userid password from the first day of class to another } \\
\text { day, which would result in a smoother first day. Mr. Ryan voiced concerns that faculty were } \\
\text { looking for more direction for the fall semester, to allow them to plan appropriately for their } \\
\text { classes. He also suggested that faculty should be able to decide how hybrid classes will be } \\
\text { run. } \\
\text { - } \\
\text { lack of a clear plan for the return in the fall semester. She urged the College to prioritize the } \\
\text { health and safety of the faculty as the plans are made. She felt that faculty should have the } \\
\text { ability to make their own choice on the teaching modality they would prefer to use } \\
\text { considering the pedogeological aspect and a health and safety aspect for the faculty member } \\
\text { and their family, especially if the faculty member is immunocompromised or a loved one } \\
\text { they are taking care of. } \\
\text { - } \\
\text { about the Fall Semester and the planning process. She urged the decisions to include the } \\
\text { faculty and allow faculty to decide how they would deliver their teaching materials. } \\
\text { - } \\
\text { representative of the Faculty he voiced concerns on the lack of a clear plan for the Fall } \\
\text { Semester which will guarantee the safety of faculty and students, allow Faculty to choose } \\
\text { the teaching modalities they would like to use to deliver their materials, and urged the } \\
\text { College to include the faculty in the decision-making process as we move forward. }\end{array}$ \\
\hline $\begin{array}{l}\text { Ocean County } \\
\text { College, Toms } \\
\text { River, NJ. }\end{array}$ & $\begin{array}{l}\text { President's Report to the Board of Trustees (August 2020)-a revision to OCC's } \\
\text { FY } 2021 \text { budget is on Thursday's agenda for approval. The revision projects a } 7 \% \\
\text { reduction in enrollment. } \\
\text { May } 2020 \text { Minutes: Dr. Garcia shared e-Learning has been working with } \\
\text { department deans to duplicate master course shells for face-to-face courses with online } \\
\text { content should the need for continued remote instruction for the remainder of the summer } \\
\text { sessions and the fall semester. } \\
\text { - Numerous speakers presented information on technology to meet ADA compliance } \\
\text { in STEM courses as well as how universal design helps all students perform better. } \\
\text { - Deans drafted a document outlining expectations and guidelines for remote } \\
\text { instruction. } \\
\text { - Since June, OCC went from having } 2 \text { Instructional designers to a total of } 7 \text { between } \\
\text { full time and part-time and utilized Cares Act funding }\end{array}$ \\
\hline
\end{tabular}

\section{4-Year College/Universities}

\begin{tabular}{|l|l|}
\hline $\begin{array}{l}\text { Name of } \\
\text { Institution }\end{array}$ & Data Collected \\
\hline $\begin{array}{l}\text { Rutgers } \\
\text { University, }\end{array}$ & $\begin{array}{l}\text { - July 6, 2020 President's letter published to their website indicated all } 2020 \text { semester } \\
\text { thaw will combine a majority of remotely delivered courses with a limited number of in-person } \\
\text { classes }\end{array}$ \\
Brunswick, & $\begin{array}{l}\text { President's letter (Jonothan Holloway, July 6, 2020) "Rutgers faculty are busy } \\
\text { NJ }\end{array}$ \\
& $\begin{array}{l}\text { semester." } \\
\text { courses that are usually held on campus: (1) instruction and materials delivered remotely for }\end{array}$ \\
\hline
\end{tabular}




\begin{tabular}{|c|c|}
\hline & $\begin{array}{l}\text { asynchronous learning, (2) synchronous remote interaction, and (3) in-person instruction } \\
\text { where feasible. } \\
\text { - } \quad \text { Will loan computers/technology to faculty, staff and students to make remote learning } \\
\text { possible where/when needed } \\
\text { - The Rutgers Board of Governors took the unprecedented step of freezing tuition and } \\
\text { fees for the coming year in recognition of the financial strain so many families have felt as a } \\
\text { result of the pandemic. } \\
\text { - IT Support services and assistance for students and staff } \\
\text { - Academic support and tutoring available to students }\end{array}$ \\
\hline $\begin{array}{l}\text { Stockton } \\
\text { University, } \\
\text { Galloway, } \\
\text { NJ }\end{array}$ & 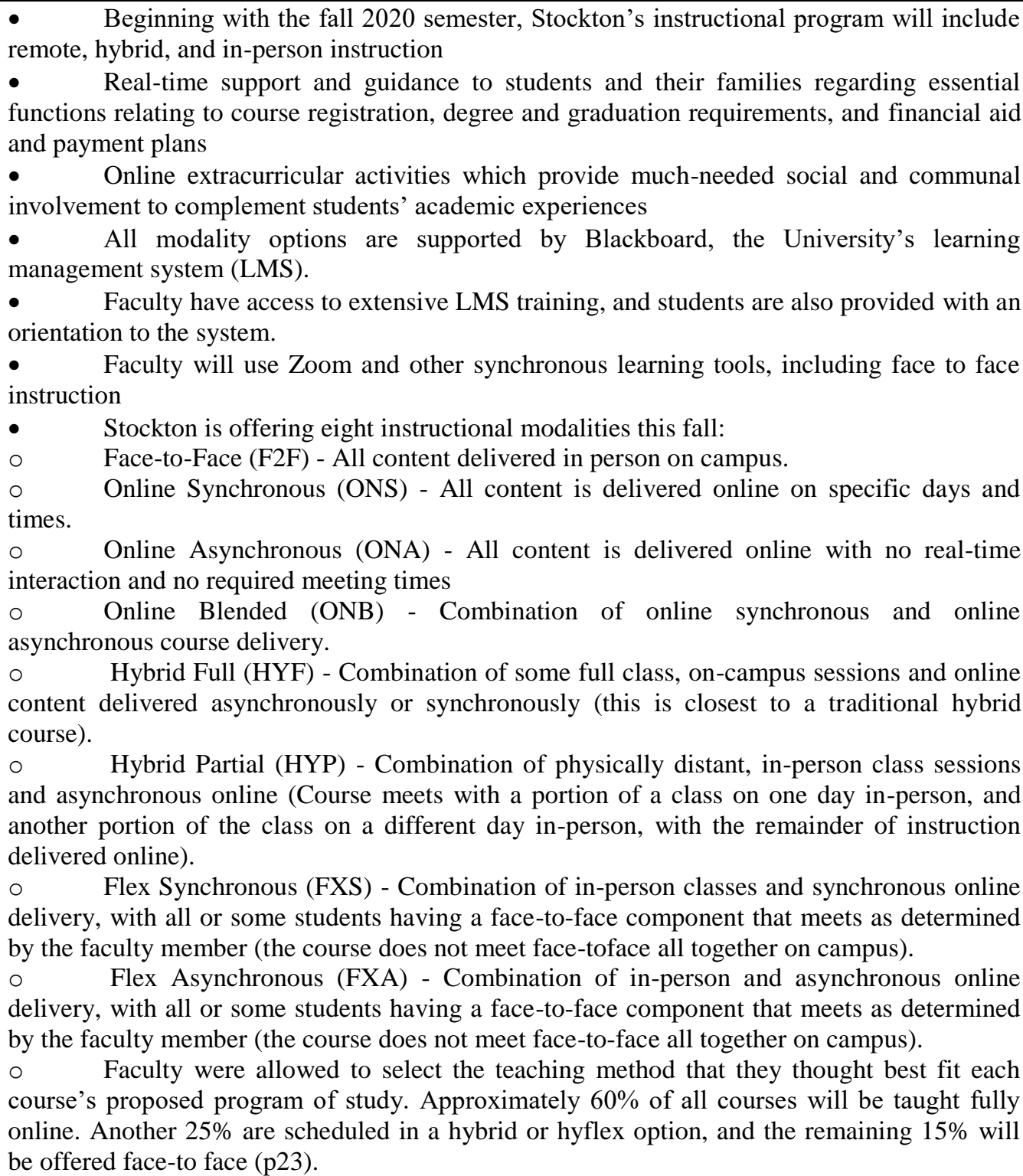 \\
\hline $\begin{array}{l}\text { William } \\
\text { Paterson } \\
\text { University, } \\
\text { Wayne, NJ }\end{array}$ & $\begin{array}{l}\text { - } \\
\text { - } \\
\text { - } \quad \text { In-peopening Fall } 2020 \text { with a mix of in-person, hybrid, hyflex and online courses. } \\
\text { The online portion of all courses, whether synchronous or asynchronous will be } \\
\text { delivered via Blackboard LMS } \\
\text { - Additional technology, including cameras to allow for in-classroom livestreaming to } \\
\text { students at a distance (i.e. hyflex) has been deployed on campus. Faculty have received } \\
\text { training from instructional design staff. } \\
\text { - } \\
\text { - Offering one on one consultations with instructional designers for faculty } \\
\text { - } \quad \text { Operating a computer loaning system for students and faculty where/when needed }\end{array}$ \\
\hline
\end{tabular}

\section{DATA ANALYSIS}

In order to evaluate the consistency or lack thereof, I analyzed data from my three data collection sources: Surveys, Interviews, and Public Data. Patterns and themes have developed to inform and 
focus future action planning. Inconsistencies among practices and perceptions are also evident. These are important because they provide required data and information regarding educator practices, skills, and beliefs regarding remote learning across multiple levels of education. The results of the analysis's are discussed, shown, and summarized below.

\subsection{Survey Data Analysis}

As I analyzed the data from the online surveys completed by 34 educators and 29 students/parents, some patterns were evident, as were inconsistenciesin regard to the perceptions and practices of remote learning practices. These will have an impact on future action plans. The following table includes my findings both quantitatively and qualitatively:

\section{Educators}

\begin{tabular}{|c|c|}
\hline Question & Analysis of Responses \\
\hline $\begin{array}{llll}\text { Do } & \text { you } & \text { teach } & \text { in } \\
\text { NY/NJ/PA/CT? }\end{array}$ & $\begin{array}{l}100 \% \text { of all responses are from educators within the same region where } \\
\text { education practices are similar. }\end{array}$ \\
\hline I feel remote learning is... & $\begin{array}{l}\text { More educators felt that remote learning was successful as opposed to not } \\
\text { successful. } \\
\text { - } 55.8 \% \text { of Educators responded that it was Successful } \\
\text { - } \quad 44.2 \% \text { of Educators responded that it was Unsuccessful }\end{array}$ \\
\hline Grade Level in Education & $\begin{array}{l}\text { The majority of the responses received came from } \mathrm{K}-12 \text { and 2-Year } \\
\text { Community Colleges. } \\
\text { - } 44.1 \% \mathrm{~K}-12 \text { Education } \\
\text { - } \\
\text { - } \\
\text { - } \quad 85.2 \% \text { 2-Year Community College } \\
\text { 8.8\% Graduate Level and Higher }\end{array}$ \\
\hline Year & 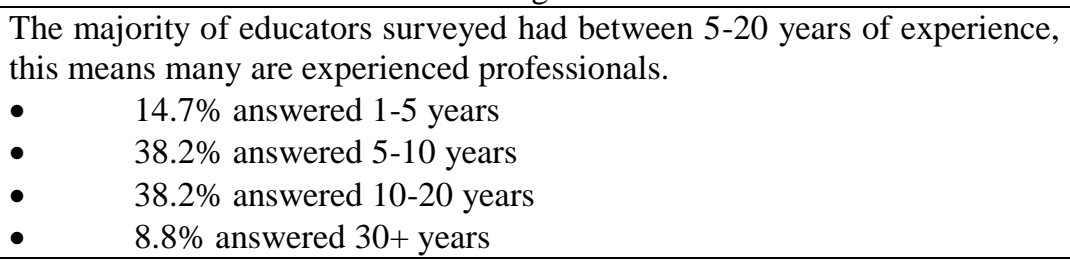 \\
\hline & $\begin{array}{l}\text { The majority of educators surveyed hold a Master's degree. } \\
\text { - } \\
\text { - } \\
\text { - } \\
\text { - } \\
\text { - } \\
\text { - } \\
\text { - } \\
\text { - }\end{array}$ \\
\hline $\begin{array}{l}\text { Prior to the COVID-19 } \\
\text { pandemic, have you taught in } \\
\text { a "remote" or "online" setting } \\
\text { before? }\end{array}$ & 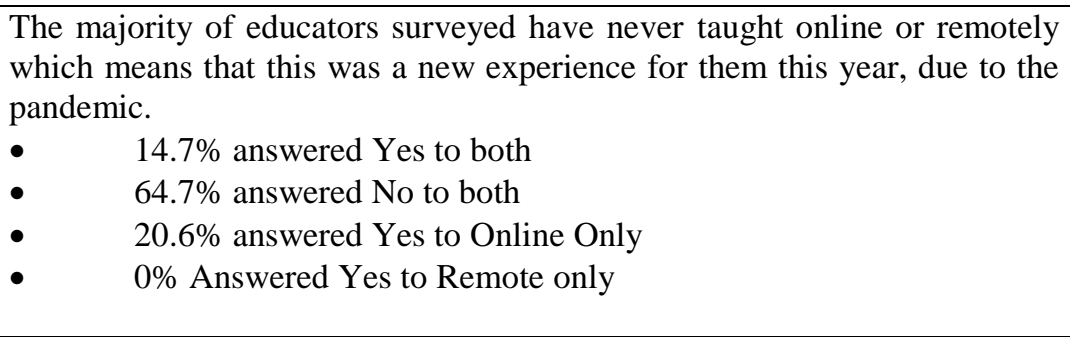 \\
\hline $\begin{array}{l}\text { Which of the following } \\
\text { methods did you use while } \\
\text { teaching remotely in } 2020 \text { ? } \\
\text { Check all and any that apply. }\end{array}$ & $\begin{array}{l}\text { The most highly used methods of instruction included: } \\
\text { - } 64.7 \% \text { Pre-recorded video or screen casting } \\
\text { - } 67.6 \% \text { Live instruction on a tech platform (examples: Zoom, } \\
\text { Google Meets, WebEx, Skype, etc) } \\
\text { - } 67.6 \% \text { Provided set hours for students to arrange one on one time } \\
\text { with me } \\
\text { - } 79.4 \% \text { Answered student questions/issues via e-mail } \\
\text { - } \quad 76.5 \% \text { Asked students to turn in all assignments electronically } \\
\text { - } 64.7 \% \text { Created opportunities for students to engage with each } \\
\text { other (via live sessions or asynchronous tools such as Flipgrid, Voice } \\
\text { Thread, discussion boards, etc) } \\
\text { - } 82.4 \% \text { Set clear guidelines that were posted on how and when to }\end{array}$ \\
\hline
\end{tabular}




\begin{tabular}{|c|c|}
\hline & $\begin{array}{l}\text { contact you } \\
\text { - } 73.5 \% \text { Set clear guidelines for receiving extra help with } \\
\text { assignments or to ask questions } \\
\text { - } 76.5 \% \text { Used videos from sources like TedEd, YouTube, Khan, etc } \\
\text { - } \quad 6.5 \% \text { Interacted with students regularly } \\
\text { - } \quad 7.6 \% \text { Provided detailed feedback on assignments } \\
\text { - } \quad \text { my roster } \\
\text { - } \\
\text { The least used methods of instruction included: } \\
\text { - } 52.9 \% \text { Provided to make personal connections with every student on } \\
\text { - } 50 \% \text { Reviewed and posted expectations for students such as, how } \\
\text { long completing a lesson or assignment will take, when assignments are } \\
\text { due, and how to submit their work } \\
\text { - } 38.2 \% \text { Provided students with packets or paper materials } \\
\text { - } 5.9 \% \text { Asked students to turn in all assignments on paper } \\
\text { - } 26.5 \% \text { Asked students for a mix of on-paper and electronic } \\
\text { assignments } \\
\text { - } 38.2 \% \text { Scanned my paper packets and posted to the LMS (Google } \\
\text { Classroom, Blackboard, Canvas, etc) } \\
\text { - } 47.1 \% \text { Differentiated content for students (example, provided } \\
\text { different ways for them to learn the lesson or complete the assessment) } \\
\text { - } 50 \% \text { Communicated the lesson's learning objective with the } \\
\text { students } \\
\text { language barriers, } 504 / \text { IEP accommodations } \\
\text { - } 52.9 \% \text { Asked for student feedback about their learning }\end{array}$ \\
\hline $\begin{array}{l}\text { I feel I have received } \\
\text { adequate training and/or } \\
\text { professional development to } \\
\text { teach remotely }\end{array}$ & $\begin{array}{l}\text { More educators felt they did not receive adequate training or PD to teach } \\
\text { remotely. } \\
\begin{array}{l}\text { - } \\
\text { - }\end{array} \quad 42.9 \% \text { Disagree } \\
\end{array}$ \\
\hline $\begin{array}{l}\text { I would rate my comfort in } \\
\text { using technology to teach from } \\
1-5 \text {, with } 5 \text { being the highest }\end{array}$ & $\begin{array}{l}\text { The majority of educators surveyed described themselves at least a 3-5 } \\
\text { with their comfort in using technology. } \\
\text { - } \quad 0 \% \text { answered } 1 \\
\text { - } \\
\text { - } \\
\text { - } \\
\text { - } \\
\text { - } \\
\text { - } 35.5 \% \text { answered } 2 \\
\end{array}$ \\
\hline $\begin{array}{l}\text { I received guidelines on how } \\
\text { to deliver remote learning } \\
\text { from my school or } \\
\text { institution... }\end{array}$ & $\begin{array}{l}\text { The majority of educators surveyed said they received guidelines to teach } \\
\text { remotely. } \\
\begin{array}{l}\text { - } \\
\text { - } \\
\text { - }\end{array}\end{array}$ \\
\hline $\begin{array}{l}\text { Do you agree or disagree with } \\
\text { the following statement: } \\
\text { "Remote learning doesn't } \\
\text { work." }\end{array}$ & $\begin{array}{l}\text { More than half of educators surveyed did not agree that remote learning } \\
\text { doesn't work, about } 1 / 5 \text { remained neutral, and } 1 / 3 \text { agreed that it does not } \\
\text { work. This leads me to wonder what about it does or does not work. } \\
\text { - } 23.5 \% \text { Agree } \\
\text { - } \\
\text { - } \\
\text { - } \\
\text { - } \\
\text { - } \\
\text { 17.6\% Strongly Agree } \\
\text { 17.6\% Strongly Disagree }\end{array}$ \\
\hline $\begin{array}{l}\text { I felt my students were } \\
\text { engaged while receiving } \\
\text { remote learning }\end{array}$ & $\begin{array}{l}\text { More than half of educators felt they were able to keep their students } \\
\text { engaged during remote learning. } \\
\text { - } \\
\text { - } \\
25.9 \% \text { Agree } \\
\text { - } \\
\text { - } \\
\text { - } \\
\text { - } 2.9 \% \text { Strongly Agree } \\
\end{array}$ \\
\hline $\begin{array}{l}\text { Do you feel that remote } \\
\text { learning could be improved by }\end{array}$ & $\begin{array}{l}\text { The most educators found that their administrators needed more } \\
\text { professional development and training on remote learning than they did; }\end{array}$ \\
\hline
\end{tabular}


any of the following? Check all that apply.

they also responded that they would like more professional development, parent involvement, and peer interaction in the remote setting.

The majority of educators felt remote learning could be improved by the following:

- $64.7 \%$ More professional development and/or training for administrators or leadership making decisions

- $61.8 \%$ More professional development and/or training for educators

- $\quad 52.9 \%$ Parent involvement

- $\quad 55.9 \%$ Peer Interaction

- $\quad 50 \%$ Flexibility in schedule

- $\quad 50 \%$ Small group settings during live instruction

- $\quad 50 \%$ Structured learning schedules

Less educators felt that remote learning could be improved by:

- $\quad 32.4 \%$ Additional technology tools

- $\quad 17.6 \%$ More asynchronous learning

- $\quad 29.4 \%$ More synchronous learning

- $\quad 38.2 \%$ More one on one opportunities to interact with students

- $\quad 47.1 \%$ More assistance/support for students (and their families where applicable)

- $\quad 38.2 \%$ More structured communication

- $38.2 \%$ More direct instruction

- $\quad 2.9 \%$ Less direct instruction

- $\quad 2.9 \%$ None listed

- $\quad 0 \%$ Other (feedback can be shared at the end)

$44.1 \%$ of educators surveyed reported that they did not enjoy teaching remotely, $20.6 \%$ remained neutral, and $35.3 \%$ enjoyed teaching remotely.

- $\quad 23.5 \%$ Agree

- $\quad 11.8 \%$ Strongly Agree

- $\quad 20.6 \%$ are Neutral

- $\quad 23.5 \%$ Disagree

- $\quad 20.6 \%$ Strongly Disagree

$70.6 \%$ of Educators felt connected to their students while teaching remotely.

- $\quad 61.8 \%$ Agree

- $\quad 8.8 \%$ Strongly Agree

I felt engaged with my $\bullet \quad 8.8 \%$ are Neutral

students while teaching $\bullet \quad 17.6 \%$ Disagree

$\begin{array}{lll}\text { remotely } & \bullet & 2.9 \% \text { Strongly Disagree }\end{array}$

\section{Students (and parents)}

\begin{tabular}{|c|c|}
\hline Question & Analysis of Responses \\
\hline $\begin{array}{l}\text { Do you (or your child) attend } \\
\text { school in any of the following } \\
\text { US States: New York, New } \\
\text { Jersey, Pennsylvania, or } \\
\text { Connecticut? }\end{array}$ & $\begin{array}{l}100 \% \text { of all responses are from students/parents within the same region } \\
\text { where education practices are similar. }\end{array}$ \\
\hline $\begin{array}{l}\text { Which of the following best } \\
\text { describes you? }\end{array}$ & $\begin{array}{l}\text { The majority of responses came from parents even though the survey was } \\
\text { equally distributed amongst parents and students. } \\
\begin{array}{l}\text { - } \\
\text { - }\end{array} \quad 62.9 \% \text { Student } \\
\end{array}$ \\
\hline $\begin{array}{l}\text { My remote experience varied } \\
\text { by instructor/teacher }\end{array}$ & $\begin{array}{l}\text { The majority of those surveyed found that their experience varied by } \\
\text { instructor/teacher. } \\
\text { - } 82.8 \% \text { True } \\
\text { - } \quad 17.2 \% \text { False }\end{array}$ \\
\hline $\begin{array}{l}\text { The grade level that best } \\
\text { describes my or my child's }\end{array}$ & $\begin{array}{l}\text { The majority of responses came from K-12 (58.6\%) and 2-Year } \\
\text { Community Colleges }(20.7 \%) \text {. }\end{array}$ \\
\hline
\end{tabular}




\begin{tabular}{|c|c|}
\hline remote learning experience & $\begin{array}{ll}\text { - } & 51.7 \% \mathrm{~K}-8 \\
\text { - } & 6.9 \% \text { High School } \\
\text { - } & 20.7 \% \text { 2-Year Community College } \\
\text { - } & 13.8 \% \text { 4-Year college of University } \\
\text { - } & 3.4 \% \text { Graduate Level } \\
\text { - } & 3.4 \% \text { Professional Program or Certification }\end{array}$ \\
\hline $\begin{array}{l}\text { During remote learning, I or my } \\
\text { child had access to }\end{array}$ & $\begin{array}{l}\text { Two-thirds of the responses indicated they have access to some sort of } \\
\text { assistance to complete their remote learning while One-third said they } \\
\text { had access to none. } \\
\text { - } 48.3 \% \text { A parent at home to help } \\
\text { - } 10.3 \% \text { A sibling at home to help } \\
\text { - } 17.2 \% \text { Tutoring } \\
\text { - } 10.3 \% 1: 1 \text { help from educators at my child's educational } \\
\text { institution } \\
\text { - } 34.5 \% \text { None of these }\end{array}$ \\
\hline I feel I learn better when & $\begin{array}{l}\text { The majority of responders indicated a desire for a mix of both } \\
\text { asynchronous and synchronous learning experiences during remote } \\
\text { learning. } \\
\text { - } 20.7 \% \text { The learning experience is synchronous(live, in real } \\
\text { time) for a specific time window of hours } \\
\text { - } 13.8 \% \text { The learning experience is asynchronous (not live) but } \\
\text { needs to occur during a specific time window of days } \\
\text { - } \quad 65.5 \% \text { A mix of both }\end{array}$ \\
\hline $\begin{array}{l}\text { In my experience, I feel that } \\
\text { remote learning is... }\end{array}$ & $\begin{array}{l}\text { More than half of those surveyed agreed that their remote learning } \\
\text { experience was successful. } \\
\text { - } \quad 55.2 \% \text { Successful } \\
\text { - } \quad 44.8 \% \text { Unsuccessful }\end{array}$ \\
\hline $\begin{array}{l}\text { Prior to COVID-19, have you } \\
\text { (student) enrolled in any type of } \\
\text { online educational programming } \\
\text { or remote learning situation? }\end{array}$ & $\begin{array}{l}\text { Prior to the pandemic of } 2020,75.9 \% \text { of those surveyed has no } \\
\text { experience with remote or online education previously. } \\
\text { - } 24.1 \% \text { Yes } \\
\text { - } \quad 75.9 \% \text { No }\end{array}$ \\
\hline $\begin{array}{l}\text { Rate the student's comfortability } \\
\text { with technology (if parent, rate } \\
\text { the child not yourself) } 1 \text { being } \\
\text { the lowest and } 5 \text { being the most } \\
\text { comfortable. }\end{array}$ & 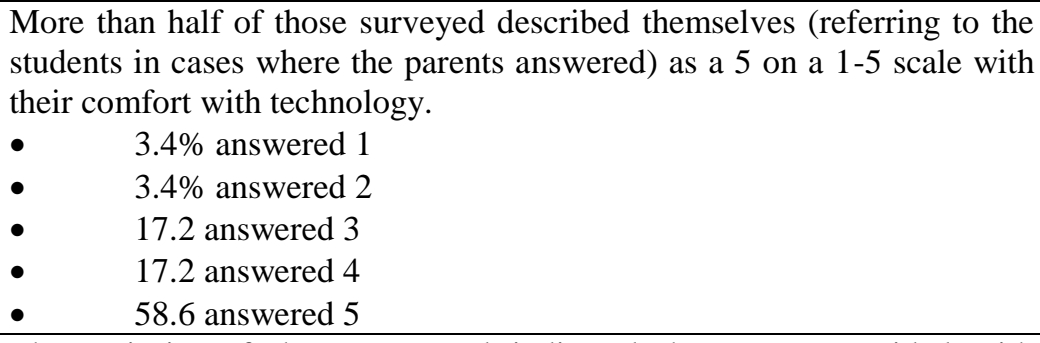 \\
\hline $\begin{array}{l}\text { Did your school provide } \\
\text { information and guidance on } \\
\text { how to access remote learning } \\
\text { and what it would entail during? }\end{array}$ & $\begin{array}{l}\text { The majority of those surveyed indicated they were provided with } \\
\text { information and guidance on remote learning. } \\
\text { - } 62.1 \% \text { Yes } \\
\quad 37.9 \% \text { No }\end{array}$ \\
\hline $\begin{array}{l}\text { Do you agree with the } \\
\text { following statement, "Remote } \\
\text { learning doesn't work." }\end{array}$ & $\begin{array}{l}\text { The results here are divided, } 41.4 \text { reported that remote learning "did not } \\
\text { work" and } 44.8 \% \text { believed it did work. } \\
\text { - } 20.7 \% \text { Agree } \\
\text { - } \\
\text { - } \\
\text { - } \\
\text { - } \\
\text { - } \\
\text { 13.7. } \\
\text { 10.3\% Strongly Agree }\end{array}$ \\
\hline $\begin{array}{l}\text { I (referring to the student) felt } \\
\text { engaged during remote learning, } \\
\text { check the following box that } \\
\text { closely matches your response. }\end{array}$ & 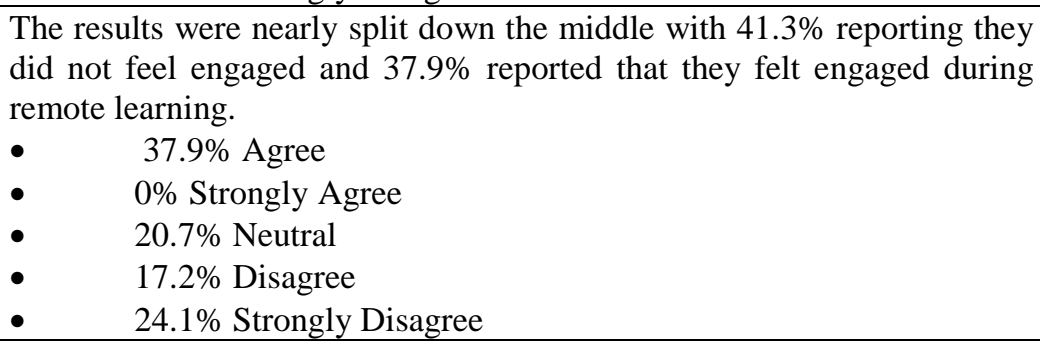 \\
\hline $\begin{array}{l}\text { During your (student's) remote } \\
\text { learning experience, please }\end{array}$ & $\begin{array}{l}\text { The survey results indicated that the most common instructional methods } \\
\text { included pre-recorded videos from YouTube/Ted Ed/Khan, followed by }\end{array}$ \\
\hline
\end{tabular}


select any of the following that was part of your experience: pre-recorded videos from the teachers/instructors. Less reported having synchronous instruction take place during remote learning.

*In the previous survey by educators, more than $60 \%$ of educators reported using live conferencing to deliver remote learning AND prerecorded videos but only $24.1 \%$ of students/parents reported receiving live instruction and $\mathbf{4 8 . 3 \%}$ reported receiving pre-recorded videos from their educators.

Most of those surveyed reported that the following was a part of their remote learning experience:

- $\quad 62.1 \%$ YouTube/TedEd/Khan Academy and other videos were shared

- $\quad 48.3 \%$ Pre-recorded instruction from my individual teacher was provided as either a video/screen cast

- $41.4 \%$ My teacher or professor tried to make personal connections with me

- $\quad 41.4 \%$ I knew where to get help if I had a question

Less of those surveyed reported that the following was a part of their remote learning experience:

- $\quad 20.7 \%$ Grading was clearly explained by personalized feedback from my teacher or professor

- $\quad 6.9 \%$ Grading rubrics were provided on assignments and expectations were clear

- $\quad \mathbf{2 4 . 1 \%}$ Live instruction was provided via Zoom, Skype, WebEx, Google Meets, or some other program

- $\quad 37.9 \%$ Only work and assignments were posted, no instruction was provided

- $\quad 48.3 \%$ My teacher/professor was available to answer my questions and interacted with me

- $\quad 27.6 \%$ My teacher/professor was not available to answer my questions and did not interact with me

- $\quad 24.1 \%$ I did not try to contact my teacher at all individually

- $\quad 13.8 \%$ My school sent home paper packets of materials that were needed

- $\quad 37.9 \%$ My assignments were completed entirely online and did not require paper/printer

- $\quad 3.4 \%$ My assignments were completed on paper and needed to be turned in on paper

- $\quad 27.6 \%$ My assignments were on paper and needed to be scanned and turned in electronically

- $\quad 24.1 \%$ I had opportunities to engage with my peers and teacher during remote learning in real-time

- $\quad 37.9 \%$ I had opportunities to engage with my peers and teaching during remote learning asynchronously (via Flip Grid, Pre-recorded media software, Voice Thread, Discussion boards, etc.)

- $\quad 20.7 \%$ I understood the expectations for my classes, including what I needed to do, how long it would take, and when it was due

I (student) knew how to navigate my online learning system (Google Classroom, Blackboard, Canvas, Moodle, etc)

Most of those surveyed knew how to access and navigate their remote learning materials through an LMS.

- $\quad 86.2 \%$ Yes

- $13.8 \%$ No

The majority surveyed indicated that they learn best from doing something hands-on.

- $24.1 \%$ Video

- $\quad 17.2 \%$ Audio or Podcast

- $\quad 6.9 \%$ Reading Text

- $\quad 79.3 \%$ Learning from doing something hands-on 


\begin{tabular}{|c|c|}
\hline & $24.1 \%$ Writing or taking notes \\
\hline $\begin{array}{l}\text { More of this would help } \\
\text { remote learning... }\end{array}$ & 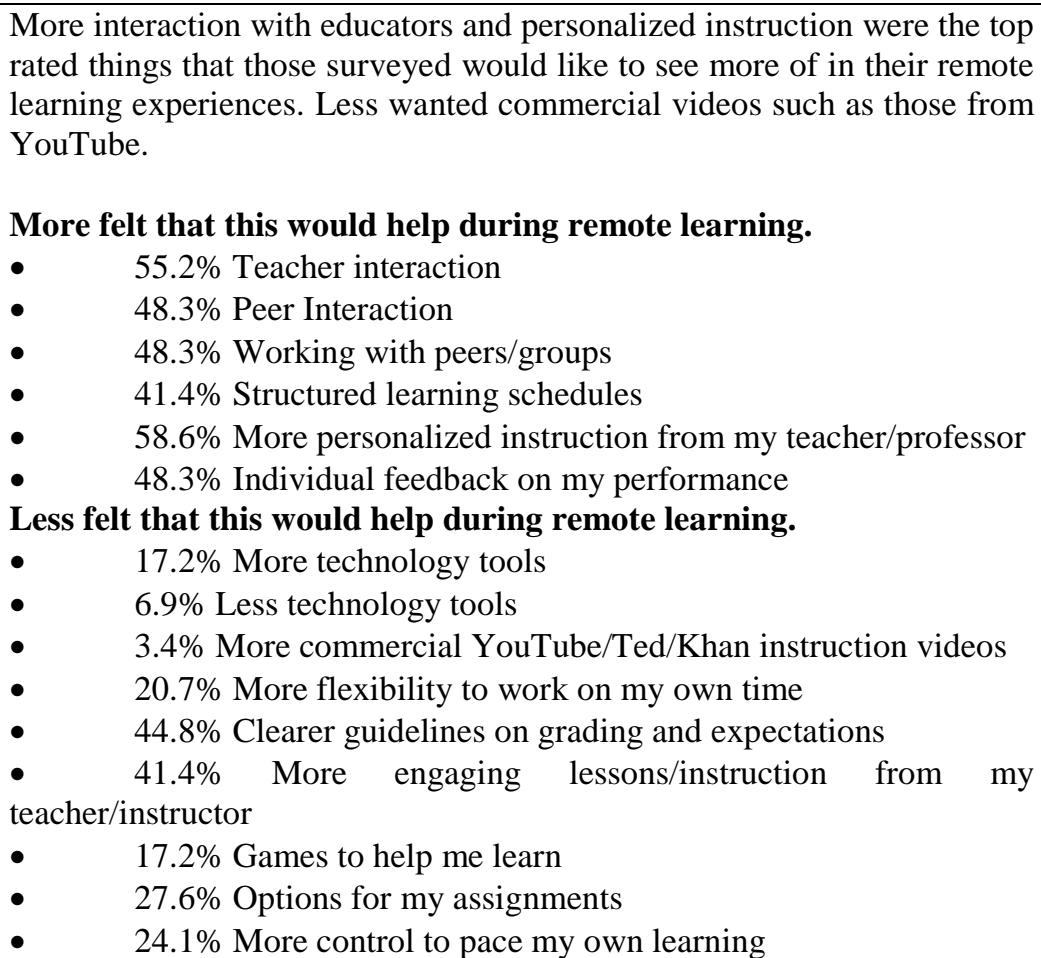 \\
\hline I enjoy learning remotely... & $\begin{array}{l}\text { Despite the challenges indicated the majority of those surveyed } 48.2 \% \\
\text { enjoyed their remote learning experience as opposed to those that didn't } \\
41.3 \% \text {. } \\
\begin{array}{l}\text { - } \\
\text { - } \\
\text { - } \\
\text { - } \\
\text { - } \\
\text { - } \\
17.3 \% \text {. } \\
\text { 17.2\% Strongly Agree } \\
\text { Strongly Disagree }\end{array}\end{array}$ \\
\hline
\end{tabular}

\subsection{Interview Data Analysis}

\begin{tabular}{|l|l|}
\hline Question & Analysis of Responses \\
\hline & $\begin{array}{l}\text { The majority of those surveyed identified themselves as } \\
\text { Deans or Assistant Deans (5), (2) were Principals, (1) Director } \\
\text { of Curriculum, (1) VP level administrator, (1) Instructional } \\
\text { Designer, and (1) Educational Technology Facilitator. }\end{array}$ \\
What is your job/role in education? & $\begin{array}{l}\text { More than half of those interviewed represent 2-Year } \\
\text { Community Colleges, 36.4\% represent K-12, and 9.1\% } \\
\text { represent 4-Year Universities. }\end{array}$ \\
$\begin{array}{l}\text { Which of the following best describes your } \\
\text { role? }\end{array}$ & $\begin{array}{l}\text { Many responded in ways that indicate that remote means } \\
\text { "live" "scheduled" or "synchronous" learning where online }\end{array}$ \\
$\begin{array}{l}\text { What do you think is the main difference } \\
\text { translates more to an "asynchronous" or "self-paced" } \\
\text { experience. Multiple responders said that both require } \\
\text { learning? }\end{array}$ \\
$\begin{array}{l}\text { During the Spring 2020 time when } \\
\text { education went remote, what were the } \\
\text { biggest obstacles for both your institution } \\
\text { and teaching staff? }\end{array}$ & $\begin{array}{l}\text { 6 of those interviewed reported a correlation to remote } \\
\text { learning struggles and the use of technology. }\end{array}$ \\
\hline $\begin{array}{l}\text { What Guidelines were in place for remote } \\
\text { learning in Spring 2020, and were they } \\
\text { enough? }\end{array}$ & $\begin{array}{l}\text { At least } 6 \text { of those who responded mentioned that there were } \\
\text { few or no specific guidelines, specifically in delivering } \\
\text { instruction. Most mentioned that guidelines have been updated } \\
\text { for Fall 2020. }\end{array}$ \\
\hline $\begin{array}{l}\text { During the Spring 2020 time when } \\
\text { education went remote, what were the } \\
\text { biggest wins or strengthens for both your }\end{array}$ & $\begin{array}{l}\text { Almost all respondents said that their faculty have more } \\
\text { experience with technology since Spring 2020. }\end{array}$ \\
\hline
\end{tabular}




\begin{tabular}{|c|c|}
\hline $\begin{array}{l}\text { istitution and teaching staff and what } \\
\text { reas need improvement? }\end{array}$ & $\begin{array}{l}\text { Multiple mentioned that staff and faculty came together and } \\
\text { were unified in their remote learning experiences or that } \\
\text { teachers/faculty are more empowered. } \\
\text { Mastering the more complicated "tech" issues needs to be } \\
\text { addressed and improved. }\end{array}$ \\
\hline $\begin{array}{l}\text { Have you (or your institution) added new } \\
\text { or additional guidelines to continue remote } \\
\text { learning in the Fall or for the future needs } \\
\text { of remote learning at your institution? If } \\
\text { so, what? }\end{array}$ & $\begin{array}{l}\text { All responded yes, that the guidelines have been } \\
\text { changed/revised/updated/improved upon. } \\
\text { More accountability for faculty and students, more } \\
\text { synchronized learning experiences, more scheduled learning, } \\
\text { and more training were the most popular answers. }\end{array}$ \\
\hline $\begin{array}{l}\text { How do you think students view remote } \\
\text { learning? }\end{array}$ & $\begin{array}{l}\text { Overall, some liked remote learning and some preferred in } \\
\text { person learning experiences. Many agreed that the experiences } \\
\text { are not similar or the same. }\end{array}$ \\
\hline $\begin{array}{l}\text { How does your faculty/teaching staff view } \\
\text { remote learning? }\end{array}$ & $\begin{array}{l}\text { While many agreed that it was challenging, multiple } \\
\text { responders agreed that their faculty stepped up even though } \\
\text { nothing replaces in-person learning. } 3 \text { responded that their } \\
\text { teachers enjoyed the creativity it allowed for. }\end{array}$ \\
\hline $\begin{array}{l}\text { What is the most important part of a } \\
\text { quality remote learning experience? }\end{array}$ & $\begin{array}{l}\text { The answers varied but included support, technology, } \\
\text { consistency, engagement, and fun. }\end{array}$ \\
\hline $\begin{array}{l}\text { Was the student experience in remote } \\
\text { learning contingent upon their faculty } \\
\text { member and is this a positive or negative } \\
\text { factor? }\end{array}$ & $\begin{array}{l}\text { Most responders agreed that the experience was contingent } \\
\text { upon both the faculty and students (and parents where } \\
\text { applicable). }\end{array}$ \\
\hline
\end{tabular}

\subsection{Public Information Data Analysis}

It was interesting to evaluate the differences between the educational institutions. It can be noted that of the three, K-12 put the most emphasis on returning to school face-to-face whereas Higher Ed (both 2-year and 4-year institutions) put an emphasis on improving the quality of remote learning with the use of training, professional development opportunities, and two of the Higher Education institutions utilized instructional designers. All institutions appear to have altered and expanded upon their previous remote instruction guidelines from the spring 2020 terms.

\subsection{K-12}

Overall, K-12 districts put a high emphasis and weight on face to face learning experiences holding more value, specifically for younger and students with disabilities. All districts are providing more professional development opportunities and training for their staff; some more detailed about what that training entails and others not. Some districts specifically shared their technology tools and plans with the public while others did not.

\begin{tabular}{|c|c|}
\hline $\begin{array}{l}\text { Institution/Locat } \\
\text { ion }\end{array}$ & Analysis of Data Collected \\
\hline $\begin{array}{l}\text { Hazlet } \\
\text { Township Public } \\
\text { School District, } \\
\text { Hazlet, NJ } \\
\text { (Monmouth } \\
\text { County) }\end{array}$ & $\begin{array}{l}\text { The youngest students are given the most face to face instruction while the older students } \\
\text { MS-HS are remote more often. Leadership demonstrated high competence in using } \\
\text { technology to communicate with the community; } 3 \text { days of professional development and } \\
\text { training are set aside for faculty/staff; technology tools such as Google Classroom and } \\
\text { Google Apps were identified; tutoring is being offered to HS students who need it. }\end{array}$ \\
\hline $\begin{array}{lr}\text { Toms } & \text { River } \\
\text { Public } & \text { School } \\
\text { district, } & \text { Toms } \\
\text { River, } & \text { NJ } \\
\text { (Ocean County) }\end{array}$ & $\begin{array}{l}\text { All students are remote at the beginning of the school year except for those in specific } \\
\text { disability programming. All staff will receive } 3 \text { days of dedicated professional } \\
\text { development and training, some specifically geared to special education services; both } \\
\text { synchronous and asynchronous instruction were specifically mentioned; several remote } \\
\text { learning tools were specifically mentioned such as Jamboard, Brainpop, and Virtual } \\
\text { Science labs; massive layoffs were also mentioned in their plans. }\end{array}$ \\
\hline $\begin{array}{l}\text { Pemberton } \\
\text { Township } \\
\text { School District, } \\
\text { Pemberton, NJ } \\
\text { (Burlington }\end{array}$ & $\begin{array}{l}\text { All students are starting remote and will be provided with } 1: 1 \text { technology for all; live } \\
\text { access to their teachers and synchronized instruction is specifically mentioned; specified } \\
\text { times and guidelines are in place for extra support and tutoring; screen time restrictions } \\
\text { are in place for younger students; specific technology tools were not detailed but } \\
\text { communication from leadership was professional, organized, and shows competence in }\end{array}$ \\
\hline
\end{tabular}


\begin{tabular}{|l|l|} 
County) & using technology to communicate. \\
\hline
\end{tabular}

\section{2-Year Community Colleges}

All three colleges analyzed moved the majority of their instruction remote for the fall 2020 terms; all discussed the need for faculty training and support at their board meetings; only one college in this category publicly weighed in on the importance of the role of instructional design and implemented a more uniform approach in offering instructional shells to their faculty.

\begin{tabular}{|c|c|}
\hline $\begin{array}{l}\text { Institution/Locati } \\
\text { on }\end{array}$ & Analysis of Data Collected \\
\hline $\begin{array}{l}\text { Bergen County } \\
\text { Community } \\
\text { College, } \\
\text { Lyndhurst, New } \\
\text { Jersey. }\end{array}$ & $\begin{array}{l}\text { Both students and faculty expressed concern over course structure and guidelines at the } \\
\text { board meeting; a "Train the Trainer" program was noted as being implemented to guide } \\
\text { faculty through continued remote learning efforts. }\end{array}$ \\
\hline $\begin{array}{l}\text { Brookdale } \\
\text { Community } \\
\text { College, } \\
\text { Lincroft, NJ. }\end{array}$ & $\begin{array}{l}\text { Faculty expressed concerns at the board meeting that structure and guidance is needed to } \\
\text { continue learning online for the fall semester; expressed concerns over a lack of a clear } \\
\text { plan; requested faculty have more control in the decision making on how to deliver } \\
\text { teaching materials and run hybrid programming. }\end{array}$ \\
\hline $\begin{array}{lr}\text { Ocean } & \text { County } \\
\text { College, } & \text { Toms } \\
\text { River, NJ. }\end{array}$ & $\begin{array}{l}\text { The college reported plans to create courses in the remote master shells from the } \\
\text { college's catalogue of prebuilt online master courses created by a team of subject matter } \\
\text { experts and instructional designers; the college announced a series of professional } \\
\text { development for staff on remote teaching, STEM tools, and ADA compliance in the } \\
\text { online environment to support faculty; the deans put together their own guidelines for } \\
\text { their faculty that outline the expectations for both faculty and students in the remote } \\
\text { environment for fall 2020; OCC utilized Cares Act funding according to their BOT clips } \\
\text { to expand their instructional design team to support face to face faculty in transitioning } \\
\text { their materials online for the fall terms. One of the interview responder also sent a guide } \\
\text { created by the Deans that outlines remote learning modalities and expectations- this was } \\
\text { an addition since the spring term. }\end{array}$ \\
\hline
\end{tabular}

\section{4-Year Colleges/Universities}

Of the three institutions analyzed, two publicly announced their plans for more than one format of remote/hybrid learning; specifically Stockton that offered 8 different modalities to accommodate the needs of their students. All of the universities are offering devices and IT/Academic support to their communities; William Paterson publicly acknowledged and discussed their instructional design staff to assist faculty.

\begin{tabular}{|c|c|}
\hline $\begin{array}{l}\text { Institutio } \\
\mathrm{n} / \text { Locatio } \\
\mathrm{n}\end{array}$ & Analysis of Data Collected \\
\hline $\begin{array}{l}\text { Rutgers } \\
\text { Universit } \\
\text { y, New } \\
\text { Brunswic } \\
\text { k, NJ }\end{array}$ & $\begin{array}{l}\text { It was announced that a temporary freeze on all tuition costs and fees is in place; courses will } \\
\text { mostly remain remote for the fall term and include both synchronous and asynchronous learning } \\
\text { experiences; some limited courses will be held on campus; technology will be loaned to any } \\
\text { student or faculty in need; extended academic support, IT support, and tutoring will be made } \\
\text { available to students during this time. }\end{array}$ \\
\hline $\begin{array}{l}\text { Stockton } \\
\text { Universit } \\
\text { y, } \\
\text { Galloway } \\
\text { NJ }\end{array}$ & $\begin{array}{l}\text { Real-time support will be made for students in advising, academic support, and technical } \\
\text { support; this includes online extracurricular activities; faculty have extensive training in } \\
\text { Blackboard and Zoom (two main tools being utilized); the University has customized } 8 \text { different } \\
\text { instructional models to meet the needs of all students; Approximately } 60 \% \text { of all courses will be } \\
\text { taught fully online. Another } 25 \% \text { are scheduled in a hybrid or hyflex option, and the remaining } \\
15 \% \text { will be offered face-to face }\end{array}$ \\
\hline $\begin{array}{l}\text { William } \\
\text { Paterson } \\
\text { Universit } \\
\text { y, } \\
\text { Wayne, } \\
\text { NJ }\end{array}$ & $\begin{array}{l}\text { Multiple modes of remote, hybrid, hyflex, and in-person learning is offered to meet student's } \\
\text { needs; both synchronous and asynchronous learning experiences available; faculty have been } \\
\text { trained and supported by instructional design staff; one on one consultations available for } \\
\text { faculty with instructional designers; devices and remote tutoring available for students in need }\end{array}$ \\
\hline
\end{tabular}




\subsection{Future Action Plan}

As I look at the data I have collected and analyzed, I continue to notice inconsistencies in the way that educators report their practices versus how students and parents experience them. In addition, institution's approaches to remote learning vary significantly where some define and detail specific plans whereas others do not, and the way they prepare their staff and plan for the fall is drastically different-some institutions have put a deeper emphasis on returning to school rather than improving remote learning and yet some put a lot of effort into their remote learning by purchasing additional technology and utilizing instructional designers. Through the collected quantitative and qualitative data, I now have a much better understanding of the current practices, skills, beliefs, and attitudes educators and administrators have in remote learning. I am very pleased in the willingness of my colleagues across multiple institutions (and their contacts) in contributing to the survey and interviews in this action research. I think this is due to the fact that they are also proactive in seeking to implement guidelines for remote learning. This only "illuminates teachers' commitment to their professions and to the students they serve" (Heubeck E. 2020).

While remote learning was not the desired modality of instruction for many participants in the surveys and interviews, including: educators, students, parents, and administrators, the overall perceptions varied between their responses. $67.6 \%$ of educators reported having provided live synchronous instruction whereas only $24.1 \%$ of students and parents surveyed experienced such instruction. The administrators mostly blamed technology and parent-involvement for the K-12 students and selfmotivation and lack of faculty technology skills for those in higher education. I would have liked to gain a clearer picture of how the students actually performed in their remote learning courses to evaluate against the data collected.

Actions to take next in order to address and possibly resolve this issue include; sharing results of this action research project with education leaders, surveying more students about their experiences, and forming a team of individuals (including educators, administration, and professionals) to draft plans for remote learning and professional development opportunities that meets the needs of educators to provide consistency in all virtual classrooms. Being aware of what other institutions are doing and evaluating their best (and possibly unsuccessful) practices can help foster further collaboration and innovation in addressing the remote learning needs of both faculty and students. Future actions will allow for further understanding and application of best practices to create a more unified, consistent, remote learning approach delivered and experienced by all.

\section{FORCE FIELD ANALYSIS}

Throughout this action research project, I have gained needed insight and data to help answer my research questions. It is evident that further guidelines and training on remote learning were required by all educational institutions heading into the fall 2020 terms. The following force field analysis includes the goals and objectives of my action plan. It also lists possible driving and restraining forces that have the potential of impacting the implementation of this plan, further solving the problem, and constructing further guidelines to meet the needs of continued remote instruction.

\section{Goal of Action Plan:}

The primary goal of this action plan is to obtain, clarify, and evaluate the practices, beliefs, skills, and attitudes that educators, students, and parents have regarding remote learning in order to effectively improve consistency and clarify expectations.

\section{Objectives:}

To reporton all participants an understanding of the practices, skills, and attitudes others have remote learning from spring 2020 and adjustments needed to continue remote learning in the fall 2020 terms.

To evaluate guidelines for remote learning practices that are consistent, and takes into account the skills, needs, and attitudes of those continuing remote learning at their institutions in the future.

\begin{tabular}{|l|l|}
\hline $\begin{array}{l}\text { Driving Forces } \\
\text { (Needs/supports making success more likely) }\end{array}$ & $\begin{array}{l}\text { Restraining Forces } \\
\text { (Barriers to success) }\end{array}$ \\
\hline $\begin{array}{l}\text { Sharing of current practices, skills, beliefs, } \\
\text { and attitudes with other participants of various levels } \\
\text { of education. }\end{array}$ & $\begin{array}{l}\bullet \text { Time to develop and implement plans and } \\
\text { guidelines } \\
\text { Creation of a focus group for further } \\
\text { analysis and data collection } \\
\text { Surveying students (and parents where } \\
\text { practices or learn technology outside of their comfort } \\
\text { zones from educators to change their } \\
-\quad \text { Resistance from students to change their }\end{array}$ \\
\hline
\end{tabular}




\begin{tabular}{|c|c|}
\hline $\begin{array}{l}\text { applicable) } \\
\text { - } \quad \text { Identifying best practices } \\
\text { - } \\
\text { - } \\
\text { Evaluating guidelines for consideration } \\
\text { - } \quad \text { Revising drafts of guidelines after allowing } \\
\text { ample time for collaboration, feedback and } \\
\text { suggestions } \\
\text { Identify the gaps and skills needed to } \\
\text { improve remote learning } \\
\text { - Hands-on learning opportunities during } \\
\text { remote instruction }\end{array}$ & $\begin{array}{l}\text { attitudes and motivation in their education } \\
\text { - Resistance from parents to understand } \\
\text { and/or take a more active role in their child's } \\
\text { education } \\
\text { Parental involvement } \\
\text { Personal bias of participants } \\
\text { - Obtaining additional relevant data on } \\
\text { student performance versus the data obtained from } \\
\text { surveys and interviews } \\
\text { - Utilizing best practices } \\
\text { - } \quad \text { Reliance on traditional learning } \\
\text { environments } \\
\text { The Digital Divide and Access to } \\
\text { technology } \\
\text { Holding educators accountable for } \\
\text { following guidelines } \\
\text { - } \text { Relying on students (and parents where } \\
\text { applicable) to take a more active role in their } \\
\text { education when remote }\end{array}$ \\
\hline
\end{tabular}

The main objectives of this force field analysis are to: address with all participants an understanding of the practices, beliefs, skills, and attitudes others have regarding remote learning and to evaluate guidelines for remote instruction that are consistent, and takes into account the skills, needs, and attitudes of those continuing to participate in remote learning in the future. This will assist in meeting the goal of obtaining, clarifying, and evaluating the practices, beliefs, skills, and attitudes that educators, students, and parents have regarding remote learning in order to effectively improve consistency and clarify expectations. Without taking into account the views of all possible participants, it would be difficult to determine and collaborate on guidelines for the future.

In moving forward, additional driving forces impacting the effectiveness of a policy have surfaced. Through the initial data collection, surveys, and interviews that were conducted, many educators mentioned the need for administrators to better understand remote learning as well as parent involvement being a contributor to their success. I believe that it is important to obtain information directly from more students as well, and data on their actual performance, instead of solely relying on how educators and parents believe about remote learning and its effectiveness. Surveying students and their performance data will provide accurate quantitative and qualitative data that parents and administrators may not be aware of. This can be done through surveying a larger pool of students in a similar way teachers were surveyed for further analysis and incorporation into future policies and to collect statistical data from educational institutions on student grades before the COVID-19 pandemic switch to remote learning and compare it to student grades collected during remote learning. Also, in order to educate and inform administrators and educational decision makers of other practices, beliefs, and skills regarding technology, it would be beneficial to share the findings of my initial action research. This could be done in a variety of ways including discussion panels and forums, and providing copies of the information and data already collected for further reflection, analysis, and data collection. From there, focus groups could be created that include educators and parents or educators and students to continue the process and finally collaborate on standard guidelines for implementation. Furthermore, these guidelines should specifically address educational practices during remote instruction to address the $73.3 \%$ of responders that indicated learning best from a hands-on approach.

\subsection{Potential Evaluation Data Sources for Future Action Plan}

As indicated in the force field analysis, many questions and restraining forces still exist. By also including more students and their actual performance statistics in data collection and focus groups, their views can be considered as well since only $37.9 \%$ of those surveyed were actually students. The needs of educators, administrators, parents, and students should all be taken into account. Further data collection, surveys, discussion, and information are important in the construction of consistent remote learning guidelines and best practices. It will take further time and cooperation with the participants, but the benefits will be well worth it. If and when remote learning guidelines are adopted and implemented, it will be important to maintain performance tracking on their effectiveness and determine future modifications. This should happen on a regular basis. During and post 
implementation data should also come from all participants and be both qualitative and quantitative in nature. This could include additional surveys, interviews, focus groups, and data collection.

\section{CONCLuSion}

The switch to remote learning has achieved one thing in particular- every educator regardless of their previous technology skills has a better understanding of technology despite whether or not they see its role as valuable in their instructional practices. Research has also confirmed that educators will come together during times of need for their students. By using action research to determine whether or not remote learning was successful this year, it was also found that layers of other factors contribute to the situation overall, this was determined by collecting data from a variety of perspectives. While it was hoped that a full 360-degree analysis could be achieved, student performance data across multiple levels of educational institutions would have helped to make more solidified conclusions that answer the ultimate question being asked - does remote learning work? My conclusion is sometimes, when consistent, structured, and tailored to meet the specific needs of students and dependent upon a variety of factors that include the way students learn, prefer to learn, and the support they need and/or have available to them. Unfortunately, outside factors such as technology and parent involvement can take away from the remote learning experience causing negative perceptions with the educational process.

The literature review I conducted will continue to guide me in this action research as well as future research projects in that it is important to value the use of technology in the physical classrooms as the foundation for continued use in remote learning settings; it is also critical to provide structure and consistency alike in both environments. I have decided on the methodology and conducted formative data collection to use in answering my questions about remote learning practices and the need for further guidelines and consistencies. The qualitative and quantitative data have been gathered and organized; it has also been analyzed and an action plan solidified. Patterns in the participants' practices, beliefs, skills, and attitudes have emerged as results were summarized. The force field analysis indicates more still needs to be done and that more can be learned on student performance data during remote learning to make further conclusions about whether or not remote learning was truly successful or unsuccessful. Input and suggestions from peers will continue to be welcomed regarding this formative action research.

The purpose of this action research was to gain a better understanding of remote learning practices, guidelines, and educator beliefs about whether or not remote learning works and is equal to in-person learning. The problem of not having consistent guidelines in teaching remotely is an issue seen and heard about on a regular basis during the COVID-19 pandemic. Through this process, the varying experiences among educators, administrators, educational technology professionals, students, and parents alike have helped me gain a better understanding of what practices were done in regards to teaching remotely, multiple perspectives within educational institutions regarding those practices, and the perceived results based on what has been done as well as indicators of what needs to be done.

Based on the results of this research, it is evident that a variety of practices, skills and beliefs exist among/between all participants related to remote learning. Some are based on tradition, some are based on best practices or learning from failed practices, and others are based solely on educator's views or opinions preference and their individual comfort ability with the face-to-face environment. It is my intention that conducting action research and implementing future action plans on this topic will assist in improving and resolving our current situation, and help guide future practices and policies effective. It would also be interesting to see, in future studies, what the perceived environment for face-to-face instruction actually looks like and whether or not it is truly more effective at closing learning gaps and barriers.

\section{REFERENCES}

[1] Board of Trustees Meeting (July 2020), Brookdale Community College, Lincroft, NJ. http://www.brook dalecc.edu/documents/board-of-trustees/board-packets/2020-board-packets-and-materials/BOT-PBM-July28-2020-public-packet-revised.pdf

[2] Bozkurt, A., Insung Jung, Junhong Xiao, Vladimirschi, V., Schuwer, R., Egorov, G., Lambert, S. R., AlFreih, M., Pete, J., Olcott Jr., D., Rodes, V., Aranciaga, I., Bali, M., Alvarez Jr., A. V., Roberts, J., 
Pazurek, A., Raffaghelli, J. E., Panagiotou, N., de Coëtlogon, P., \&Shahadu, S. (2020). A global outlook to the interruption of education due to COVID-19 Pandemic: Navigating in a time of uncertainty and crisis. Asian Journal of Distance Education, 15(1), 1-126. https://doi.org/10.5281/zenodo.3878572

[3] Calco, A. M. (2020). Returning to Rutgers-institutional restart plan. https://coronavirus.rutgers. edu/returning-to-rutgers-institutional-plan-for-restart/

[4] Dartmouth University (2020) Remote teaching good practices: beyond the teach. Teaching Guides, Retrieved from https://sites.dartmouth.edu/teachremote/remote-teaching-good-practices/

[5] Gregory, C., Lampley, J. (2016). Community college student success in online versus equivalent face-toface courses, Journal of Learning in Higher Education, 12(2), 63-72. https://files.eric.ed.gov/fulltext/EJ11 39733.pdf

[6] Hazlet Township Public Schools (2020) News \& announcements, a message from the superintendent of schools. https://www.hazlet.org/

[7] Heubeck E. (2020) Education week asks teachers: how did COVID-19 change your teaching, for better or worse? Education Week, Vol 39, Issue 34, pp. 10-11. Retrieved from https://www.edweek.org/ew/articles/ 2020/06/03/how-did-covid-19-change-your-teaching-for.html

[8] Holloway, J. (2020). Fee Reduction for Rutgers Students. https://www.rutgers.edu/president/fee-reductionrutgers-students

[9] Johnson, S. G., \& Berge, Z. (2012). Online education in the community college. Community College Journal of Research and Practice, 36(11), 897-902. doi:10.1080/10668920903323948

[10] Lederman, D. (2020). The Role of Learning in Colleges' Decisions about Fall. Inside Higher Ed. Retrieved from https://www.insidehighered.com/digital-learning/article/2020/07/01/presidents-give-their-collegesmixed- grades-remote-learning-how

[11] Mandinach, E. B., Parton, B. M., Gummer, E. S., \& Anderson, R. (2015). Ethical and appropriate data use requires data literacy. Phi Delta Kappan, 96(5), 25-28. https://doi.org/10.1177/0031721715569465

[12] Mannion, A. (2020). Higher Education in Transition: Regional Colleges and Universities Focus on Future of Learning Whether In-Person or Online. Northwest Indiana Business Quarterly Magazine, 24-27.

[13] Pemberton Township Schools. (2020) School restart \& reopening plan fall 2020. https://www.pemberton.k12.nj.us/Page/4863

[14] President's Report to the Board of Trustees (August 2020). Ocean County College, Toms River, NJ. https://www.ocean.edu/news/dr-larsons-report-to-the-occ-board-of-trustees-24/

[15] Presidents Report to the Board of Trustees Meeting Minutes (July 2020). Bergen County Community College, Lyndhurst, New Jersey. https://bergen.edu/wp-content/uploads/July-7-2020-Final-BoardMinutes.pdf

[16] Ray, K. (2020). The remote learning experience. Tech \& Learning, (SI), 6+. Retrieved from https://linkgalecom.libproxy.ocean.edu/apps/doc/A627691112/PROF?u=toms86543\&sid=PROF\&xid=795e84c6

[17] Ray, K. (2020). What Is Remote Learning? Tech \& Learning, (SI), 4. Retrieved from https://link-galecom.libproxy.ocean.edu/apps/doc/A627691111/PROF?u=toms86543\&sid=PROF\&xid=51bc1096

[18] Stockton University Restart Operations Committee (2020). Institution plan for fall 2020 restart. 3-40. https://stockton.edu/return/documents/stockton-university-fall-restart.pdf?1599091149439

[19] Toms River Regional Schools (2020). Three day PD series will highlight enhanced virtual learning. https://www.trschools.com/community/three-day-pd-series-will-highlight-enhanced-virtual-learning

[20] Toms River Regional Schools (2020). 2020-2021 back to school plan. https://www.trschools.com/ community/tr-safe-return

[21] Wali, A. Z., \&Popal, A. W. (2020). The Emerging Issues and Impacts of Technology in Classroom Learning. International Journal of Emerging Technologies in Learning, 15, 237-245. https://doi.org/10. 3991/ijet.v15i15.14175

[22] William Paterson University (2020). The reopening plan - a return to on-campus teaching, living, and working. https://www.wpunj.edu/reopening/

[23] Wojciechowski, A., \& Palmer, L. B. (2005). Individual student characteristics: Can any be predictors of success in online classes? Online Journal of Distance Learning Administration, 8(2). Retrieved June 29, 2015, from http://www.westga.edu/ distance/ojdla/summer82/ wojciechowski82.htm

\section{AUTHOR'S BIOGRAPHY}

Laura Wingler, is a Lead Instructional Designer at Ocean County College in Toms River, NJ and has been teaching at various colleges as an adjunct in Arts \& Humanities since 2014. She received her MFA in Creative Writing from Western Connecticut State University in 2010 and completed her 
Master of Education in Instructional Design and Technology at the American College of Education in 2021.

Citation: Laura Wingler, Nalucha Gaudencia. "Does Remote Learning Work? Action Research" International Journal of Humanities Social Sciences and Education (IJHSSE), vol 8, no. 8, 2021, pp. 32-65. doi: https://doi.org/10.20431/2349-0381.0808005.

Copyright: (ㅇ 2021 Authors. This is an open-access article distributed under the terms of the Creative Commons Attribution License, which permits unrestricted use, distribution, and reproduction in any medium, provided the original author and source are credited. 